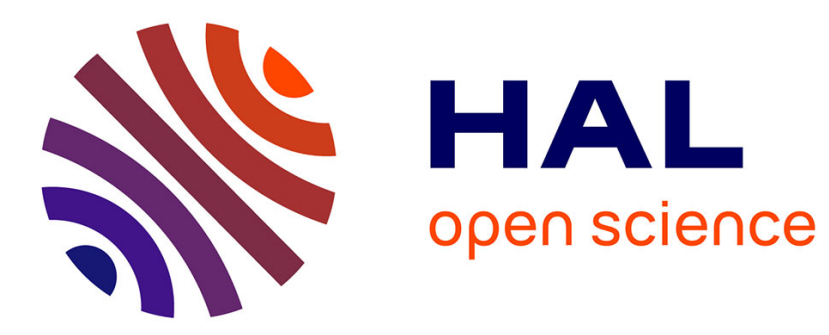

\title{
The status of water in swelling shales: an insight from the water retention properties of the Callovo-Oxfordian claystone
}

\author{
Hamza Menaceur, Pierre Delage, Anh Minh A.M. Tang, Jean Talandier
}

\section{To cite this version:}

Hamza Menaceur, Pierre Delage, Anh Minh A.M. Tang, Jean Talandier. The status of water in swelling shales: an insight from the water retention properties of the Callovo-Oxfordian claystone. Rock Mechanics and Rock Engineering, 2016, 10.1007/s00603-016-1065-2 . hal-01774681

\section{HAL Id: hal-01774681 \\ https://hal-enpc.archives-ouvertes.fr/hal-01774681}

Submitted on 15 May 2018

HAL is a multi-disciplinary open access archive for the deposit and dissemination of scientific research documents, whether they are published or not. The documents may come from teaching and research institutions in France or abroad, or from public or private research centers.
L'archive ouverte pluridisciplinaire HAL, est destinée au dépôt et à la diffusion de documents scientifiques de niveau recherche, publiés ou non, émanant des établissements d'enseignement et de recherche français ou étrangers, des laboratoires publics ou privés. 
The status of water in swelling shales: an insight from the water retention properties of the Callovo-Oxfordian claystone

Hamza MENACEUR ${ }^{12}$, Pierre DELAGE $^{1}$, Anh Minh $_{\text {TANG }}{ }^{1}$, Jean TALANDIER $^{3}$

${ }^{1}$ Ecole des Ponts ParisTech, Navier, CERMES, France

${ }^{2}$ Now in LEMTA, Université de Lorraine, Nancy, France

${ }^{3}$ Andra, Chatenay-Malabry, France

Corresponding author:

Pierre Delage

Laboratoire Navier/CERMES

Ecole des Ponts ParisTech

6-8 av. Blaise Pascal

77455 MARNE-LA-VALLEE

France

Tel : +33.1.64.15.35.42

Fax : +33.1.64.15.35.62

Email :delage@cermes.enpc.fr 


\section{Abstract}

The Callovo-Oxfordian ( $\mathrm{COx}$ ) claystone is considered in France as a possible host rock for the disposal of high level long lived radioactive waste at great depth. During the operational phase, the walls of the galleries and of the disposal cells will be successively subjected to desaturation induced by ventilation followed by resaturation once the galleries are closed. To better understand this phenomenon, a sound understanding of the water retention properties of the COx claystone is necessary. Following a previous study by the same group, this paper presents an investigation of microstructure changes of $\mathrm{COx}$ claystone under suction changes. Microstructure was investigated by means of mercury intrusion porosimetry tests on freeze-dried specimens previously submitted to various suctions. Along the drying path, the initial microstructure, characterised by a well classified unimodal pore population around a mean diameter value of $32 \mathrm{~nm}$, slightly changed with the same shape of the PSD curve slightly moved towards smaller diameters $(27-28 \mathrm{~nm})$ at suctions of 150 and $331 \mathrm{MPa}$, respectively. The infra-porosity too small to be intruded by mercury (diameter smaller than $5.5 \mathrm{~nm}$ ) reduced from $4.3 \%$ to $3.3 \%$. Oven-drying reduced the mean diameter to $20 \mathrm{~nm}$ and the infra-porosity to $1 \%$. Wetting up to $9 \mathrm{MPa}$ suction leads to saturation with no significant change of the PSD curve, whereas wetting at zero suction gave rise to the appearance of a large pore population resulting from the development of cracks with width of several micrometers, together with an enlargement of the initial pore population above the mean diameter. The concepts describing the step hydration of smectites (by the successive placement within the clay platelets along the smectite faces of 1,2, 3 and 4 layers of water molecules with respect to the suction applied) appeared relevant to better understand the changes in microstructure of the COx claystone under suction changes. This also allowed to better define the status of water in claystones and shales containing smectite, with a distinction made between the water adsorbed within the clay platelets and the free inter-platelet water, involved in hydro-mechanical couplings through changes in pore pressure and water transfers. 


\section{Introduction}

The French Radioactive Waste Management Agency (Andra) is currently considering the Callovo-Oxfordian claystone (COx), an indurated clay rock 155 million years old (limit upper-middle Jurassic), as a potential host rock for radioactive waste disposal at great depth. An Underground Research Laboratory (URL) has been excavated at a depth of $490 \mathrm{~m}$ by Andra in the $150 \mathrm{~m}$ thick layer of the COx claystone close to the village of Bure in the North-east of France in order to carry out in-situ experiments and to assess the reliability of the host rock as a geological barrier for radioactive waste confinement (Lebon and Mouroux 1999, ANDRA 2005). Due to the excavation and ventilation of the galleries, the close field around the galleries and the disposal cells is prone to desaturation, that will be followed by progressive resaturation by the pore water from the host rock at the end of the operating stage once the galleries are closed. Better knowledge of the water retention properties of the COx claystone is hence necessary.

Particular attention has been paid in recent years to investigate the significant water sensitivity of claystones. By carrying out Environmental Scanning Electron Microscope (ESEM) observations on COx claystones samples submitted to cyclic changes in relative humidity, Montes-Hernandez et al. (2004) observed the water sensitivity of the clay fraction, with significant successive openings and closures of cracks. Valès (2008), Bornert et al. (2010) and Wang et al. (2014) also evidenced the appearance of cracks resulting from hydration under zero stress conditions by using Digital Image Correlation (DIC) at microscopic scale. The water retention properties of the COx claystone have been investigated by Pham et al. (2007) who evidenced some hysteresis effects together with the changes in ultrasonic velocity and in strain induced by hydration cycles on COx samples at various controlled relative humidities. Boulin et al. (2008) determined the water retention curve of the COx claystone from its pore size distribution (determined by mercury intrusion porosimetry) and found reasonable agreement with the main wetting path of the water retention curve. Ferrari et al. (2014) proposed a detailed analysis of the water retention properties of the Opalinus clay.

This paper is following a former one from the same group by Wan et al. (2013) who provided a complete description of the changes in water content, volume and degree of saturation of the COx claystone along drying and wetting paths, also evidencing the swelling shrinkage behaviour of the claystone under controlled suction and hysteresis 
effects. In this paper, a better understanding of the water retention properties of the COx claystone is looked for thanks to a study of the microstructure changes (investigated by means of mercury intrusion porosimetry) due to changes in suction along various paths of the water retention curve. Finally, some new insights on the status of water in clay rocks and shales containing smectite are provided.

\section{Material and methods}

\subsection{The COx claystone}

The COx claystone is a sedimentary rock deposited 155 millions years ago on top of a layer of Dogger limestone that was afterwards covered by an Oxfordian limestone layer. The thickness of the COx layer is about $150 \mathrm{~m}$. The COx claystone is composed of a clay matrix containing some detritic grains of quartz and calcite. The mineralogical composition of the COx claystone varies with depth, particularly in terms of clay fraction and carbonate content. At the depth of the Bure URL (490 m), the average mineralogical composition of COx claystone is as follows (Gaucher et al. 2004): 45 $50 \%$ clay fraction (mainly interstratified minerals of illite-smectites with a fraction between 50 and $70 \%$ of smectites according to Yven et al. 2007), 20\% carbonate, $22 \%$ quartz and 9\% other minerals (feldspars, pyrite, dolomite and siderite ). The total connected porosity varies in the COx layer between $14 \%$ in carbonated levels and $19.5 \%$ in the more argillaceous levels (Yven et al. 2007).

The specimens were drilled from a $80 \mathrm{~mm}$ diameter and $300 \mathrm{~mm}$ long core (EST44584) parallel to bedding that was extracted at the level the URL (490 m). The water content was determined after drying in the oven at $105{ }^{\circ} \mathrm{C}$ for 48 hours. The porosity and degree of saturation were calculated from carefully measuring the sample volume by using hydrostatic weighing. The initial total suction was determined by using a dew point tensiometer (WP4, Decagon). The specimens EST44584 appeared to be not fully saturated at initial state with a degree of saturation around $79.1 \%$ corresponding to a suction of $34 \mathrm{MPa}$ for a porosity of $17.3 \%$. The dry density and grain density values are 2.23 and $2.7 \mathrm{Mg} / \mathrm{m}^{3}$, respectively. Partial saturation resulted from the combined actions of coring, transport, storage and specimen preparation. 


\subsection{Experimental techniques}

The core was confined within a plastic tube immediately after having been drilled from the borehole until the preparation of samples for laboratory experiments. In spite of this precaution, macroscopic cracks were observed after opening the core. The bedding plane of the COx specimens makes it quite difficult to trim samples without breaking them. All tests were run on specimens of $38 \mathrm{~mm}$ in diameter and between $8-10 \mathrm{~mm}$ in height. To do so, the cylinder core was firstly sliced by using a diamond wire saw at low speed in dry condition in order to preserve the integrity of the sample, to obtain a cylinder sample of $80 \mathrm{~mm}$ in thickness. The cylinder was then placed in a special metal confining mould and cored to the desired diameter $(38 \mathrm{~mm})$ by using a diamond barrel in dry condition. Finally, seven small specimens of $8-10 \mathrm{~mm}$ in thickness were obtained from the cylinder of $38 \mathrm{~mm}$ diameter by using the diamond wire saw.

The determination of the water retention properties of the COx claystone was carried out by controlling suction through the vapour phase (Delage et al. 1998). This technique consists in placing the specimens into desiccators containing saturated saline solutions. There is no confinement on the sample that is free to swell or shrink. The highest suction (331 MPa) was imposed with a saturated saline solution of $\mathrm{KOH}$. A smaller value of $150 \mathrm{MPa}$ was imposed by using $\mathrm{MgCl}_{2}$. Zero and $9 \mathrm{MPa}$ of suction were imposed by using pure water and $\mathrm{KNO}_{3}$ respectively. Specimens were left in the desiccators until reaching mass stabilization (checked by periodic precision weighing). Once equilibrated, a suction measurement was made by using the Decagon WP4 dew point tensiometer to confirm the achievement of the desired value of suction. Afterwards, the specimens were immediately waxed using slush wax (at lowest possible temperature before solidification, see Wan et al. (2013) for more detail). Careful weighing was carried out prior and after waxing, giving a good determination of the wax weight and volume. The specimen volume was obtained by subtracting the wax volume from that of the waxed specimen. The wax technique was also used to obtain the specimen volume at initial state (34 MPa of suction, degree of saturation of 79.1\%). Finally, the specimens were cut into small pieces to measure their water content by oven drying $\left(48 \mathrm{~h}\right.$ at $\left.105^{\circ} \mathrm{C}\right)$. The void ratio and degree of saturation were determined by measuring the volume by means of hydrostatic weighing. 


\subsection{Microstructure investigation}

Microstructure investigation was carried out by using mercury intrusion porosimetry (MIP). MIP tests were conducted on various specimens at different suctions along the drying or wetting paths followed. To preserve the microstructure, dehydration was made by freeze-drying small pieces of claystone (1-3 $\mathrm{g}$ in weight) that were previously quickly frozen by immersion in slush nitrogen. Slush nitrogen was obtained by applying vacuum on liquid nitrogen, bringing down its temperature from $-196^{\circ} \mathrm{C}$ (boiling temperature) to $-210^{\circ} \mathrm{C}$ (freezing temperature). Fast immersion in slush nitrogen is preferable because no boiling occurs around the specimen, resulting in faster freezing of water with no volume change (see Tovey and Wong 1973, Gillott 1973, Delage and Pellerin 1984 and Delage et al. 2006 for more details). MIP tests were carried out in a Micromeritics-AutoPore IV 9500 porosimeter from a low initial pressure of $3.4 \mathrm{kPa}$ up to $227.5 \mathrm{MPa}$, corresponding to entrance pore diameters of $363.6 \mu \mathrm{m}$ and $5.5 \mathrm{~nm}$ respectively.

The intruded mercury porosity $\left(n_{H g}\right)$ was defined as the ratio of mercury intrusion volume $V_{H g}$ to specimen total volume $V$ :

$n_{H g}=\frac{V_{H g}}{V}$

The pore entrance diameter $(D)$ was determined from the intrusion pressure $P_{H g}$ by assuming a cylindrical pore shape according to the Laplace-Young equation:

$D=\frac{4 \sigma \cos \theta}{P_{H g}}$

where $\sigma$ is the mercury-solid interfacial tension and $\theta$ is the mercury-solid contact angle $\left(\sigma=0.484 \mathrm{~N} / \mathrm{m}\right.$ and $\theta=141.3^{\circ}$ according to Diamond 1970).

\subsection{Test program}

A first series of samples were submitted to drying-wetting path (A1 to B2, see Table 1) from the initial water content (equal to $6.12 \%$ with a $34 \mathrm{MPa}$ suction and a degree of saturation of $79.1 \%$ ). Two specimens were simultaneously dried under suctions of 150 and $331 \mathrm{MPa}$ along the drying path, to check repeatability. Specimens A1 and B1 were used to define the specimen characteristics and to investigate their microstructure at 150 and $331 \mathrm{MPa}$ respectively. Once dried at $331 \mathrm{MPa}$, specimens A2 
and $\mathrm{B} 2$ were afterwards wetted at $9 \mathrm{MPa}$ and zero suctions, so as to determine the main wetting path. Along the wetting path, both specimens were periodically taken out from the desiccator for weighing so as to determine their water content. Their suction was also measured by means of the WP4 dew-point tensiometer. The same procedure was adopted for specimen D2 to determine the main drying path starting from zero suction.

A second series of tests corresponds to wetting-drying paths (Table 2). Starting from the initial water content $(6.12 \%)$, three other specimens (C, D1 and D2) were firstly wetted under decreasing suctions (9 $\mathrm{MPa}$ for specimen $\mathrm{C}$ and zero suction for specimens D1, D2). Specimen D2 was then used to determine the main drying path up to suctions of $150 \mathrm{MPa}$ and $331 \mathrm{MPa}$.

\section{Experimental results}

\subsection{Transient phases}

The changes in water content with respect to time from the initial state $(w=6.12 \%)$ along the drying and wetting paths for the first step are shown in Figure 1. Good correspondence can be observed for three pairs of specimens along same paths. The data show that water content equilibration is reached after 25 days at the highest imposed suction (331 MPa) and after 18 days at $150 \mathrm{MPa}$. Specimen $\mathrm{C}$ wetted at $9 \mathrm{MPa}$ suction came close to equilibrium after only 8 days. At zero suction, equilibrium cannot be reached after 40 days with final water contents of $10.6 \%$ for D1 and $10.4 \%$ for D2.

Figure 2 presents the wetting phases of specimens A2 and B2 from $331 \mathrm{MPa}$ to 9 MPa and zero suction respectively, together with the drying phase of specimen D2 from zero to $331 \mathrm{MPa}$. Subsequent wetting appeared to be significantly faster than the previous drying phases with curves starting with sub-vertical slopes. Specimen A2 came close to equilibrium (suction of $9 \mathrm{MPa}$ ) after only 10 days. Figure 2 also shows that $70 \%$ of the jump in water content from $1.6 \%$ to $7.2 \%$ observed in the $331-9 \mathrm{MPa}$ sequence (specimen A2) occurs in only 2 days. Specimen B2 reaches a water content of $11.2 \%$ at $0 \mathrm{MPa}$ with no full stabilisation, as already observed in Figure 1 for specimens D1 and D2. Starting from a wet state at zero suction $(w=10.4 \%)$, specimen D2 reaches water contents of $2.32 \%$ at $150 \mathrm{MPa}$ and $1.26 \%$ at $331 \mathrm{MPa}$. 


\subsection{Water retention curve}

The water retention curve expressed in terms of changes in water content versus suction is presented in Figure 3. The points at zero suction are arbitrarily plotted at a suction of $0.01 \mathrm{MPa}$. As described in section 2.4, starting from the initial state $(\mathrm{w}=6.12 \%$, suction $34 \mathrm{MPa}$ ), two points were obtained from two distinct specimens (A1 and B1) with a direct single step drying at controlled suctions of 150 and $331 \mathrm{MPa}$, respectively. Similarly, two other points were obtained from specimens C and D1 with a direct single step wetting at suctions of 9 and $0 \mathrm{MPa}$. Data along the main wetting and drying paths were also obtained by suction measurements and water content determination along the wetting path from 331 to $0 \mathrm{MPa}$ for specimen $\mathrm{B} 2$ and along the drying path from zero suction to $331 \mathrm{MPa}$ for specimen D2. Good correspondence is observed along the main wetting path between the data of specimens B2 and A2 that was wetted between 331 and $9 \mathrm{MPa}$, providing some confidence in the quality of the data.

Examination of the main drying and wetting paths shows that the water retention properties of the COx claystone are characterized, commonly, by a hysteresis effect. The data also show that the initial state resulting from desaturation from the in-situ saturated state is located, as expected, on the main drying path.

The wetting path starting from the initial state shows that the point at $9 \mathrm{MPa}$ of suction (specimen C) is located slightly below the main drying path, which is compatible with the position of scanning curves. This should however be checked given the small difference in water content at this suction between the wetting and drying paths. There is unfortunately no other point between $9 \mathrm{MPa}$ and zero suction along this path. The point at zero suction obtained along the main wetting path starting from the dry state at $331 \mathrm{MPa}$ (curve B2 in Figure 2) provides a water content (11.2\%) higher than that obtained after wetting the specimen from the initial water content $(10.6 \%$ curves D1 and D2 in Figure 1). This is due to the longer period of time waited for (90 days for B2 compared to 40 days for D1 and D2. In both cases, stabilization is not reached with rates of increase in water contents equal to 0.035 for D1-D2 and $0.2 \%$ /day for $\mathrm{B} 2$, respectively.

\subsection{Volume changes}

As previously described in section 2.2, the parameters determined at each suction equilibration were the water content, the volume, the porosity and the degree of 
saturation. Results are presented in terms of changes in degree of saturation versus suction in Figure 4a, in degree of saturation versus water content in Figure $4 b$, in volumetric changes versus suction in Figure $4 \mathrm{c}$ and in volumetric changes versus water content in Figure 4d. The data taken from similar tests by Pham et al. (2007) and by Wan et al. (2013) are also plotted, with good agreement between the data (the degrees of saturation higher than $100 \%(101.3 \%)$ observed in the data of Wan et al. 2014 in the saturated zone of Figure $4 \mathrm{a}$ are thought to be due to uncertainties in volume change measurements, made by using hydrostatic weighing).

As already commented in detail by Wan et al. (2013), the specimen following the wetting path from the initial state comes close to saturation at $9 \mathrm{MPa}\left(S_{r}=98.1 \%\right.$, $w=7.65 \%$, Figure 4b). At suction smaller than $9 \mathrm{MPa}$, the significant increase observed in water content (Figure 4b) occurs in quasi-saturated condition. Along the drying path from initial state, a linear relationship is observed between the degree of saturation and the water content with an average decrease of $13 \%$ in degree of saturation for a decrease of $1 \%$ in water content. The main wetting curve obtained once the specimen has been dried to the highest suction $(331 \mathrm{MPa})$ is located below the curves of drying-wetting from initial state (Figure 4a), confirming the hysteresis observed by Wan et al. (2013).

The changes in volumetric strain with respect to suction (Figure 4c) show that the drying from the initial state to $331 \mathrm{MPa}$ of suction results in a shrinkage of $2.3 \%$ while wetting to zero suction induces a swelling strain of $6.0 \%$. Figure $4 \mathrm{c}$ also shows that reducing suction along the wetting path from initial state occurs with little swelling $(0.12 \%)$ from 34 to $9 \mathrm{MPa}$ and significant swelling below $9 \mathrm{MPa}(6.0 \%$ at zero suction). As commented above, this significant swelling occurred within a quasisaturated specimen. The specimen previously dried up to $331 \mathrm{MPa}$ before wetting to zero suction (main wetting path) is not brought back to the same point as that of the specimen submitted to a wetting path from initial state, with some irreversible swelling strain $(1.8 \%)$ and higher volume at zero suction. However, the main wetting path seems to be close to the drying curve from initial state at higher suction ( $>40 \mathrm{MPa}$ ) showing some reversibility in the volume change behaviour under stress free conditions at highest suctions. The same trends can be observed in Figure $4 \mathrm{~d}$ in terms of volume changes with respect to water content changes, with the slope of the curve close to 1 along the wetting path from the initial point at water contents between 8 and $11 \%$. 


\subsection{Mercury intrusion porosimetry}

The pore size distribution curve of the specimen at initial state $\left(S_{r}=79.1 \%\right.$, porosity $n$ $=17.3 \%$ ) is plotted in the cumulative curve of Figure $5 \mathrm{a}$ and in a density plot in Figure 5b. MIP curves are obtained from around 100 points provided by the monitoring system, resulting in an almost continuous curve and the triangles represented in the Figure are only for identification purpose.

The total porosity $n$ of the specimen is also plotted in the cumulative curve, showing that the mercury intruded porosity $n_{H g}$ is smaller than the total one, with an infra-porosity $n-n_{\mathrm{Hg}}$ of $4.3 \%$. Pores smaller than the lower limit of $5.5 \mathrm{~nm}$ (corresponding to the maximum mercury pressure of $227.5 \mathrm{MPa}$ ) cannot be intruded. The non negligible infra-porosity found here confirms previous findings on the COx claystone by Yven et al. (2007), Boulin et al. (2008) and Delage et al. (2014) who estimated the porosity not intruded by mercury at $25 \%$ of the total porosity, in accordance with the $24.8 \%$ value with diameter smaller than $5.5 \mathrm{~nm}$ found in the present research. The density function of Figure $5 \mathrm{~b}$ exhibits at initial state a typical monomodal curve with quite a well defined pore population identified by an inflection point at $32 \mathrm{~nm}$. Note that Sammartino et al. (2003), Yven et al. (2007) and Boulin et al. (2008) who performed their MIP analysis on air dried COx specimens obtained smaller average diameter of around $20 \mathrm{~nm}$. As shown by these authors, this pore population is related to the average entrance pore diameter within the clay matrix.

Figure 6 presents an enlargement between 0.001 and $0.1 \mu \mathrm{m}$ of the pore size distribution curves of specimens A1 and B2 submitted to a suction increase along the drying path up to 150 and $331 \mathrm{MPa}$ respectively from the initial state, together with the PSD data of the specimen at initial state of Figure 5 and that of a specimen oven-dried at $105^{\circ} \mathrm{C}$ for $48 \mathrm{~h}$. MIP data are presented in terms of cumulative curves (Figure $6 \mathrm{a}$ ) and density function (Figure 6b). The total porosities obtained from volume measurements are also given. The intruded mercury porosities $n_{\mathrm{Hg}}$ of the specimens dried up to 150 (A1) and $331 \mathrm{MPa}(\mathrm{B} 1)$ are equal to 12.8 and $12.2 \%$, respectively, compared to total porosities of 16.1 and $15.3 \%$, respectively, showing that the infra-porosities not intruded by mercury $(D<5.5 \mathrm{~nm})$ are again lower than the total ones. The infraporosities are smaller than that at initial state $\left(n-n_{H g}=3.3 \%\right.$ for both specimens dried up to 150 and $331 \mathrm{MPa}$, compared to $4.3 \%$ at initial state). Conversely, the mercury intruded porosity of the oven-dried specimen (12\%) appears to be quite close to the 
total one $(13 \%)$ giving an infra-porosity $n-n_{H g}=1 \%$ significantly smaller than at suctions of 150 and $331 \mathrm{MPa}(3.3 \%)$.

The degree of saturation of each specimen is also reported in Figure 6a, based on the hypothesis that water is contained in the smallest pores due to capillary effects and to the fact that physico-chemical clay water interactions occur in very small pores. The arrows indicate the maximum diameter of the pores saturated by water. One can observe that the main pore population is almost saturated (up to a diameter of $35 \mathrm{~nm}$ ) at initial state (suction $34 \mathrm{MPa}, S_{r}=79.1 \%$, mean radius $32 \mathrm{~nm}$ ) whereas this population becomes full of air at $150 \mathrm{MPa}$ suction and $S_{r}=35.1 \%$ with reduction of the mean radius at $28 \mathrm{~nm}$ and with the largest saturated pore having a diameter of $15 \mathrm{~nm}$. At 331 $\mathrm{MPa},\left(S_{r}=19.2 \%\right)$, the largest saturated pore has a diameter of around $4.9 \mathrm{~nm}$ with however no significant change in the mean radius value that slightly decreases to 27 $\mathrm{nm}$. In other words, the desaturation of pores between 15 and $4.9 \mathrm{~nm}$ does not significantly affect the microstructure at the level of both the mean pore population and of the infra-porosity that remains constant $(3.3 \%)$. Conversely, the effect of ovendrying is much stronger than drying at 150 and $331 \mathrm{MPa}$ suctions, with a reduction of the mean pore diameter to $21 \mathrm{~nm}$ and, more importantly, a significant reduction of the infra-porosity to $1 \%$. There is obviously a gap between the highest applied suction (331 $\mathrm{MPa}$ ) and the total removal of water from the microstructure by oven-drying.

The $21 \mathrm{~nm}$ mean pore diameter obtained on the oven-dried specimen is equal to the values obtained by Sammartino et al. (2003) and Boulin et al. (2008) on oven-dried specimens (dried at 105 and $70^{\circ} \mathrm{C}$, respectively). This good correspondence between pore size distribution curves obtained in different laboratories on specimens from various cores indicates that the pore size distribution of the (dry) COx claystone exhibits little variability. This is actually compatible with the good correspondence also observed on water retention curves that were independently obtained by various groups on specimens from various cores, observed in Figure 4. This good correspondence between PSD curves also provides some confidence on the reliability of MIP data. Another conclusion drawn from Figure 6 is that drying provided an under-estimated value of the mean pore diameter of the COx claystone.

In Figure 7, the pore size distribution curves of the two specimens wetted from initial state at low suctions (9 $\mathrm{MPa}$ and zero) and higher degree of saturation ( $S_{r}=98.1 \%$ and $100 \%$ for $s=9$ and $0 \mathrm{MPa}$, respectively) are presented together with 
the data at initial state $\left(S_{r}=79,1 \%, s=34 \mathrm{MPa}\right)$. Also plotted in the Figure are the total porosities of the specimens. The PSD cumulative and density function curves at $9 \mathrm{MPa}$ suction $\left(S_{r}=98.1 \%\right)$ are quite similar to that at initial state (Figure 7 a) with a only slight increase in total porosity at $9 \mathrm{MPa}(0.1 \%)$, showing that the infra-porosity is also similar in both cases. This is compatible with the negligible volume change observed in the volume change/suction curve of Figure $4 \mathrm{c}$ when passing from initial state $(s=34 \mathrm{MPa})$ to a suction of $9 \mathrm{MPa}$. The specimen saturation from $S_{r}=79 \%$ to $98 \%$ hence occurs by complete filling of the mean pore population with very little microstructure changes both in the porosity intruded and not intruded by mercury.

Figure 8 presents the PSD curves of the two specimens at $9 \mathrm{MPa}$ obtained from initial state and after drying at $331 \mathrm{MPa}$, compared to the initial state. Observation of the volume changes with respect to suction in Figure $4 \mathrm{c}$ indicates a larger volume for the sample wetted from a suction of $331 \mathrm{MPa}$. Inspection of the PSD curves of Figure 8 shows that both curves at $9 \mathrm{MPa}$ are similar with however a slight difference observed in the cumulative curve at pores larger than $6 \mu \mathrm{m}$.

The reduction in suction from $9 \mathrm{MPa}$ to $0 \mathrm{MPa}$ occurs at quasi-saturated state (see Figure $4 \mathrm{a}$ ) with a significant $6.0 \%$ swelling giving a final water content of $10.56 \%$ and degree of saturation of $100 \%$ (see Figure 4c). Indeed, significant changes are also observed at the microstructure level, as shown by the change in shape of the PSD curve of specimen D1 at zero suction that becomes bimodal. Changes affect three levels of porosity:

- i) The infra porosity $n-n_{H g}$ that increases from $4.3 \%$ at $9 \mathrm{MPa}$ to $6.4 \%$ at zero suction with an intruded porosity of $15.6 \%$ and a total one of $22.0 \%$;

- ii) The large porosity with appearance of a new pore population corresponding to a proportion of $10.3 \%$ of the total porosity in the range of diameters between 7 and $100 \mu \mathrm{m}$ with a mean diameter around $12 \mu \mathrm{m}$;

- iii) An enlargement of the previous pore population that moves from a narrow range between 12 and $50 \mathrm{~nm}$ (see density function curve in Figure $7 \mathrm{~b}$ ) to a wider range between 12 and $500 \mathrm{~nm}$ with a new plateau between 60 and $200 \mathrm{~nm}$.

Note however that no change is observed in the density function curves between 5 and $20 \mathrm{~nm}$. 
Figure 9 shows the pore size distribution curves of specimen D1 (wetted at zero suction from the initial state at 34MPa suction) and B2 (wetted at zero suction after having been submitted to a suction of $331 \mathrm{MPa}$ ). The mercury intruded porosity $n_{\mathrm{Hg}}$ of specimens D1 and B2 is equal to 15.6 and $16.6 \%$, respectively, whereas the total porosity $n$ of these specimens is 22.0 and $23.3 \%$, respectively. The porosities not intruded by mercury $\left(n-n_{H g}=6.4 \%\right.$ for D1 and $6.7 \%$ for B2) are quite close. The two PSD curves are similar, but the superimposition of the cumulative curves in the small pores area (Figure 9b) indicates that the slight change in total porosity is mainly due to changes at the level of pores larger than $2 \mu \mathrm{m}$.

In Figure 10, the PSD curves of the specimens submitted to a suction of $331 \mathrm{MPa}$ either from the initial state (34 MPa, B1) and from the wet state (zero suction, D2) after following the main wetting path are presented together and compared to the initial state. The curves at $331 \mathrm{MPa}$ are comparable and slightly differ from the curve at intact state (slight decrease in mean pore radius and decrease in infra-porosity, as commented previously). The similarity between the curves at $331 \mathrm{MPa}$ indicates that the drying of specimen D2 previously submitted to wetting at zero suction leads to complete erasing of the modifications due to hydration and swelling described above (Figure 9):

- i) The infra-porosity of the previously wetted specimen came back from $6.4 \%$ to $2.8 \%$ compared to $3.3 \%$ for that dried from initial state;

- ii) The large pores population between 7 and $100 \mu \mathrm{m}$ completely disappeared;

- iii) The mean pore population became again well classified as indicated by the peak of the density function curve with pores diameters brought back between 10 and $60 \mathrm{~nm}$.

\section{Discussion}

\subsection{Initial state}

To interpret the microstructure changes with respect to suction changes along various paths of the water retention curve observed here through MIP investigations, it was found useful to consider the conceptual model of the COx claystone microstructure presented in Figure 11 and proposed by Yven et al. (2007) from data obtained by using various techniques including scanning electron microscope, autoradiography, mercury intrusion porosimetry, oil, helium and nitrogen adsorption. The model schematically 
shows how individual calcite or quartz detritic grains are embedded into a clay matrix with interconnected porosity that represents $45-50 \%$ of total constituents at the depth of $490 \mathrm{~m}$ considered here.

The interpretation of the well defined single pore population defined by an average value of $32 \mathrm{~nm}$ observed in the PSD curve of Figure 5 can be made by assimilating the clay matrix to an assembly of bricks made up of platelets of comparable thickness, as can be seen in the scheme of Figure 11. As seen on the scheme, one can observe that the diameter of the circular pore located within the bricks provides an estimate of the brick thickness. The mean diameter detected in the PSD curve is hence used to provide an estimation of the average platelet thickness.

\subsection{The hydration of smectites}

Given the significant effects of the changes in water content (or suction) on the changes in volume (swelling-shrinkage) and in the COx claystone microstructure and given also the importance of the smectite fraction of the clay matrix in this regard, it was found useful to consider in more detail the mechanisms that govern the hydration of smectites. These mechanisms are seldom considered when interpreting the macroscopical response of swelling clay rocks and shales.

As recalled in Figure 12, the inter-basal spacing of smectites, illites and interlayer illite-smectite minerals is equal to $9,6 \AA$, given that these minerals are made up of an octahedral layer comprised between two tetrahedral layers. During hydration, the interbasal spacing of smectites is known to increase in an orderly fashion due to the successive adsorption of layers of water molecules (e.g. Mooney et al. 1952, Méring and Glaeser 1954, Norrish 1954). X-Ray diffraction techniques demonstrated that, during hydration, the successive adsorption of one, two or three layers of water molecules along the smectite minerals corresponded to interlayer spacings of 12.6, 15.6 and 18.6 $\AA$, respectively (giving a thickness of $3 \AA$ for a layer of water molecules). Another important result obtained by various authors (including Ben Rhaïem et al. 1985, Bérend et al. 1995, Cases et al. 1997, Sayiouri et al. 2004, Ferrage et al. 2005 and Ferrage et al. 2007) is that the number of layers adsorbed depended on the relative humidity (or suction) imposed during hydration. As an example, Sayiouri et al. (2004) observed in a compacted MX 80 Wyoming montmorillonite specimen that one layer of water molecules was adsorbed at suctions larger than $50 \mathrm{MPa}$, two layers between 50 
and $7 \mathrm{MPa}$ and three layers below $7 \mathrm{MPa}$, with a fourth layers adsorbed at low suctions smaller than 0.1 MPa. This mechanism is illustrated in Figure 12.

Ferrage et al. (2005) worked on purified homoionic SWy-1 montmorillonites saturated with cations of different valences (including $\mathrm{Na}^{+}, \mathrm{K}^{+}$and $\mathrm{Ca}^{++}$). They observed that hydration mechanisms were in fact more complex and heterogeneous and confirmed that hydration mechanisms also depended on the nature of the cation considered. They showed that different numbers of water layers $(0 \mathrm{~W}, 1 \mathrm{~W}$ or $2 \mathrm{~W})$ could co-exist at a given suctions above $30 \mathrm{MPa}$ (relative humidity - $\mathrm{RH}-$ smaller than $80 \%$ ). However, the average trend that they observed was compatible with the data of Saiyouri et al. (2004). On a Na montmorillonite, mainly one layer (1W) was adsorbed at relative humidity smaller than $60 \%$ (suction of $70 \mathrm{MPa}$ ) with the transition between one and two layers occurring between 60 and $80 \% \mathrm{RH}$ (suctions of 70 and $30 \mathrm{MPa}$, respectively). On a Ca montmorillonite, two layers (2W) hydration occurred at smaller $\mathrm{RH}$ value of $40 \%$ (suction of $126 \mathrm{MPa}$ ). It seems that a $95 \% \mathrm{RH}$ (suction of $7 \mathrm{MPa}$ ) can be considered as the upper limit of the two water layers hydration in smectites, as also shown by Laird et al. (1995) who observed a transition from 2 to 3 layers starting from $95 \% \mathrm{RH}$ for 5 reference smectites.

Most authors considered pure Wyoming smectites as references, but Saiyouri et al. $(2000,2004)$ also obtained the trend observed in Figure 12 with comparable values of threshold suctions between hydration stages on compacted specimens made up of a very different natural calcium/sodium smectite from France, the FoCa7 clay. In natural materials, the composition of the pore water is of course more complex. In the COx claystone, various salts mainly containing the cations $\mathrm{Na}^{+}, \mathrm{K}^{+}, \mathrm{Ca}^{++}$and $\mathrm{Mg}^{++}$are present, resulting in an overall behaviour rather typical of Ca smectites due to the significant carbonate content (Andra 2005). Based on similar trends observed in various types of smectites, a rough estimation can be made with respect to limit in suction at which the changes in $\mathrm{nW}$ adsorption state along the smectite fraction of the CallovoOxfordian could occur. It seems reasonable to consider that one layer of water molecules is adsorbed along the smectite minerals at suctions of hundreds of MPa, with a second layer at suctions of several tens of MPa with a transition comprised between 30 and $70 \mathrm{MPa}$ depending of the smectite and of the cation considered. These orders of magnitude of suction are useful in the analysis of the microstructure changes observed 
here, given the values of suction considered in the determination of the water retention curves $(0,9,150$ and $331 \mathrm{MPa})$.

\subsection{Drying phase}

Observation of the PSD curves of Figure 6Error! Reference source not found., in which the curve at initial state is compared to that at $150,330 \mathrm{MPa}$ suction and to that of the oven-dried specimen, indicates that drying is characterized by a reduction of the mean diameter of the single well defined pore population from $32 \mathrm{~nm}$ (intact) to 28 (150 MPa), $27(331 \mathrm{MPa})$ and $21 \mathrm{~nm}$ (oven-dried). This trend can also be illustrated by plotting the changes in MIP mean diameter (an estimation of the mean platelet thickness) with respect to suction, as done in Figure 13a (Figure 13b also provides the changes in infra-porosity $\left(n-n_{H g}\right)$ with respect to suction). One can observe stepwise changes in both mean diameter and infra-porosity with suction, comparable with the stepwise changes in inter-basal spacing in Figure 12. Comparable values of pore diameter and infra-porosity are observed at 9 and $34 \mathrm{MPa}$ (a suction range corresponding to two layers of adsorbed water in Figure 12) and at 150 and $331 \mathrm{MPa}$ (a suction range corresponding to one layer of adsorbed water in Figure 12). This confirms that the $\mathrm{nW}$ hydration mechanisms observed on both pure smectites and also on the natural FoCa clay can reasonably be used to analyse the changes in microstructure with suction of the Callovo-Oxfordian claystone.

Based on the brick model, the decrease in mean pore diameter corresponds to a reduction in thickness of the bricks, i.e. of the platelets. This reduction is only due to changes in the interlayer spacing of the smectite minerals within the mixed-layer illite smectite clays, given that illite minerals are not sensitive to changes in water content with a constant inter basal spacing of $9.6 \AA$. Based on the suction values given above, it can be reasonably considered that all specimens at suction higher than $150 \mathrm{MPa}$ have only one layer of adsorbed water molecules along the smectite minerals $(1 \mathrm{~W})$ within the clay platelets. At initial state and a suction of $34 \mathrm{MPa}$, the data of Sayiouri et al. (2004) would indicate the possibility of having two layers adsorbed, in reasonable compatibility with the data of Ferrage et al. (2005). The reduction of the average diameter from 32 to $28 \mathrm{~nm}$ can then be linked to the transition from two to one adsorbed layer of water molecules. 
As commented above, drying was carried out by putting the specimens during $48 \mathrm{~h}$

in the oven at $105^{\circ} \mathrm{C}$. It is well known that this temperature is not high enough to withdraw all the adsorbed water molecules in montmorillonites, which only occur at around $500^{\circ} \mathrm{C}$ (e.g. Caillère et al. 1982, Cases et al. 1992, Berend et al. 1995). Ferrage et al. (2005) observed that some homoionic SWy-1 montmorillonites had no water adsorbed $(0 \mathrm{~W})$ at $0 \% \mathrm{RH}$ (in the case of $\mathrm{Na}$ ) whereas others (with $\mathrm{Ca}$ and $\mathrm{Mg}$ ) could have some proportion of adsorption with $1 \mathrm{~W}$ hydration and, to a lesser extend, $2 \mathrm{~W}$ hydration.

It is of course difficult to extend these findings to the situation of a natural non homoionic claystone containing only a proportion of mixed-layer smectite illite with a natural pore water containing various dissolved salts. However, it is interesting to note as done above, that the average platelet thickness (deduced from the mean pore diameter) presents step variations in good agreement with the average number of water layers observed in smectites ( $2 \mathrm{~W}$ and $32 \mathrm{~nm}$ average thickness at suctions of various tens of MPa and $1 \mathrm{~W}$ and $28 \mathrm{~nm}$ thickness at various hundreds of MPa). The further decrease of diameter down to $21 \mathrm{~nm}$ after oven-drying then suggests that this state could correspond to a $0 \mathrm{~W}$ conditions. This hypothesis is compatible with the data of Ferrage et al. (2007) who investigated the effect of temperature (between 30 and $125^{\circ} \mathrm{C}$ ) on water adsorption in smectites. For a $\mathrm{Ca}$ smectite, their data showed at $105^{\circ} \mathrm{C}$ a decrease of $1 \mathrm{~W}$ adsorption from $78 \%$ to $60 \%$ together with a simultaneous increase of $0 \mathrm{~W}$ hydration from $20 \%$ to $40 \%$. In such conditions, Ferrage (personal communication) considered that the $0 \mathrm{~W}$ hypothesis was reasonable after $48 \mathrm{~h}$ at $105^{\circ} \mathrm{C}$, confirming the observation made above about the step decrease from $2 \mathrm{~W}$ hydration $(32 \mathrm{~nm}$ average platelet thickness) to $1 \mathrm{~W}$ hydration (28 $\mathrm{nm}$ average platelet thickness) and the extrapolation with $0 \mathrm{~W}$ hydration after $48 \mathrm{~h}$ in the oven at $105^{\circ} \mathrm{C}(21 \mathrm{~nm}$ average platelet thickness).

Under such a hypothesis, a rough estimation of the average number of clay layers in one platelet of mixed-layer illite-smectite can be obtained by using the mean diameter of $21 \mathrm{~nm}$ measured on the oven-dried specimen, that corresponds to the average platelet thickness. With an interlayer spacing of 9.6 $\AA$, this provides a number of 21-22 layers per platelet. Considering the proportion of 50-70\% smectite minerals provided by Yven et al. (2007) at the level considered in the COx layer, one can conclude that the introduction of one water layer along the smectite layers would result in the placement 
of between 11 and 15 layers of $3 \AA$ thick layers of water molecules, resulting in an increase in the platelet thickness between 3,3 and of 4,6 $\mathrm{nm} \mathrm{nm}$, from 21 to $24,3-25,6$ $\mathrm{nm}$. This is not far from the $28 \mathrm{~nm}$ value measured by MIP under suctions of 150 and $331 \mathrm{MPa}$. Adding another water layer would then provide a thickness between 27,6 and $30.2 \mathrm{~nm}$, reasonably comparable to the $32 \mathrm{~nm}$ measured by MIP under 34 and $9 \mathrm{MPa}$ suctions.

This indicates that the analysis based on the step hydration process evidenced in pure and compacted smectites is reasonably compatible with the analysis of the MIP data with respect to the changes in platelets thickness in the COx clay matrix with suction. Better fitting is actually obtained with the higher proportion of smectite of $70 \%$ in the clay fraction. The mechanism of hydration of smectites hence appears to be of significant interest to interpret the water retention properties and related microstructure changes of the COx claystone.

Another important point is the significant reduction of the infra-porosity to $1 \%$ after oven drying, compared to $3.3 \%$ at 150 and $331 \mathrm{MPa}$, and $4.3 \%$ at $34 \mathrm{MPa}$ (Figure 13b). This reduction can also be related to the shrinkage of platelets that also reduce the porosity of diameter smaller than $5.5 \mathrm{~nm}$. Indeed, the existence of porosity too small to be detected by MIP is well known in compacted smectites (see for instance Delage et al. 2006) whereas full intrusion has been observed in kaolinites and illites (Ahmed et al. 1974, Sridharan et al. 1971) or in natural fine-grained soils containing illite (Delage and Lefebvre 1984). Once dried, the mixed-layer platelets only have clay layers of $9.6 \AA$ inter basal spacing and behave in terms of pore configuration like illites. In other words, the bricks are shrunk enough with very small internal porosity after the expulsion of the last layer of water molecules.

\subsection{Wetting phase}

As confirmed by Figure 13, little change was observed between the sample at initial state $(34 \mathrm{MPa})$ and that at $9 \mathrm{MPa}$ both in average mean pore diameter and infraporosity, indicating that the two water layers are stable under this suction range, with the third water layer only adsorbed at suction smaller than $9 \mathrm{MPa}$.

Wang et al. (2015) investigated the nonlinearity of swelling in the COx claystone by the combined use of high resolution imaging by ESEM and Digital Image Correlation. They showed that the swelling strain was not significant and evolved 
linearly between 75 and 95\% RH (39 and $7 \mathrm{MPa}$ suction respectively), whereas it became significant between 95 and $99.8 \%$ of relative humidity. This is in agreement with the results obtained here when passing from initial state $(s=34 \mathrm{MPa})$ to a suction of $9 \mathrm{MPa}$ with a stable situation with two water layers in this suction range.

The significant swelling due to wetting at zero suction was analysed through three mechanisms in section 3.4. The mechanism i) that concerns the infra porosity can be related to the adsorption of a third or even a fourth layer of water molecules within the infra-porosity that increased from $4.3 \%$ (initial state at $34 \mathrm{MPa}$ ) to $6.4 \%$ at zero suction. Based on the hydration model used above, adding a new water layer would result in an increase of $7 \mathrm{~nm}$ in the platelet thickness, giving an average value of $39 \mathrm{~nm}$. Adding a fourth water layer would lead to an average thickness of $46 \mathrm{~nm}$. These increases in thickness are compatible with mechanism ii) with an enlargement of the diameter of the mean pore population towards larger value. It does not however explain the appearance of pores as large as 200 or $300 \mathrm{~nm}$ that can be linked to a higher degree of disorder, as observed in compacted bentonites (Sayiouri et al. 2004) in which the suction reduction below 0.1 MPa (appearance of the fourth layer) also involved a reduction in thickness of the platelets due to exfoliation of clay layers together with an increase in the number of platelets. Further investigation is necessary here in the case of the COx claystone to better understand this phenomenon.

The appearance of the large pore population with diameters between 7 and $100 \mu \mathrm{m}$ is related to the appearance of cracks that can be observed visually and have also been observed by Wang et al. (2014) by using Digital Image Correlation at microscopic level. These cracks, that are saturated as observed in Figure 4a, were suspected in the analysis of the water retention properties of the COx claystone provided by Wan et al. (2013). Observation of Figure $9 \mathrm{~b}$ indicates that a sample previously dried at $331 \mathrm{MPa}$ and brought to zero suction exhibits more large pores in the $20-30 \mu \mathrm{m}$ range, as a consequence of higher damage due to the suction cycle that in turn results in slightly larger swelling with a porosity at zero suction of $23.3 \%$ compared to $22.0 \%$ when directly wetted from initial state.

Finally, it is interesting to observe that all the pores of any kind (mechanisms i) in the infra-porosity, ii) in inter-platelets pores and iii) with cracks in the clay matrix) that developed during hydration and swelling are completely erased under high suction (331 MPa), as shown in Figure 10 in which no difference is observed between the 
specimen dried from initial state and that previously swollen. It is suspected that the cracks observed after swelling that have been closed by high suction will reopen under further rehydration.

The investigation carried out here also evidenced the roles of two distinct natures of water. Given that they correspond to suctions larger than $7-9 \mathrm{MPa}$, the layers of water molecules adsorbed within the mixed-layers illite-smectite platelets at initial state, along the drying path and even at $9 \mathrm{MPa}$ suction are heavily bonded to the smectite surfaces. Contrarily, the water molecules contained in the inter-platelets porosity with mean diameter of $32 \mathrm{~nm}$ can be considered as free water. An estimation of the relative proportion of adsorbed and free water can be obtained from the pore size distribution curve of Figure 5. According to the shape of the density function curve, the lower limit of the main pore population can be estimated at a diameter of $0.01 \mathrm{~nm}$. With a total porosity of 0.170 , the corresponding proportion of free water of the order of $67 \%$. In other words, MIP provides a porosity that is not far from that occupied by free water. It is likely that the hydro-mechanical couplings characterised by the water pore pressure as well as water transfers within the claystone are governed by this free inter-platelet water and do not concern the remaining two water molecules that are adsorbed along the smectite faces at initial state. This provide an insight into the status of water in the claystone.

\section{Conclusion}

The use of mercury intrusion porosimetry on freeze-dried specimens provided better understanding of the changes in microstructure that occur along the wetting and drying paths of the water retention curve of the Callovo-Oxfordian claystone. Interestingly, the concepts developed to describe the hydration mechanisms of smectites and their dependency with respect to suction changes appear to be applicable to the hydration of the mixed-layer illite-smectite minerals that is responsible of the change in water content and the swelling-shrinkage behaviour of the COx claystone.

The initial state of the COx specimen considered in this work is located on the main drying path of the water retention curve and characterized by a suction of $34 \mathrm{MPa}$ that corresponds to the adsorption of two layers of water molecules along the smectite faces. Releasing the suction to $9 \mathrm{MPa}$ results in the saturation of the claystone but it does not significantly affect the COx microstructure with quite little swelling and no 
change in the pore size distribution curve, in accordance with the stability of the two layers of water molecules in this suction range. Conversely, passing from $9 \mathrm{MPa}$ to zero suction allows the placement of a third, or even a fourth layer of water molecules that results in significant changes in the inter-platelets porosity. Simultaneously, a network of saturated cracks appears and the global swelling observed at zero suction comes from the combined action of the changes in the inter-platelet porosity and the generation of cracks.

Imposing suctions of 150 and $331 \mathrm{MPa}$ results in a reduction from 32 to 28-27 $\mathrm{nm}$ of the mean diameter of the pore size distribution curve, that keeps the same shape. Simultaneously, the infra-porosity not intruded by mercury with diameter smaller than $5.5 \mathrm{~nm}$ reduces from $4.3 \%$ to $3.3 \%$. Both features are in agreement with the placement of one layer of water molecules in this suction range, which explain the small differences in microstructure observed at these two suctions. Conversely, oven-drying at $105^{\circ} \mathrm{C}$ results in a further decrease to $21 \mathrm{~nm}$ in the mean diameter of the inter-platelet porosity that is coupled with a reduction of the infra-porosity to $1 \%$. These features are compatible with the state of smectite minerals at dry state, with no water layer adsorbed and an interlayer space of $9.6 \AA$.

The validity of the concepts of hydration of smectites indeed provides deeper insight in the understanding of changes in water contents and swelling-shrinkage behaviour of the COx claystone. They confirm, as also observed when comparing the water retention behaviour of powder and compacted smectites (Delage et al. 2006), that microstructure effects are mainly governed by physico-chemical interactions, with little effects of the initial fabric and structure of the claystone. In other words, the intensity of these interactions are strong enough to surpass and break the inter-particle bonding at initial state, even in the case of the strong inter-particle bonds within the clay matrix of the claystone. It seems possible that these conclusions might also help to better understand the self-sealing behaviour of the claystones that contain a significant proportion of smectites, like the Callovo-Oxfordian claystone or the Opalinus clay. More generally, these findings should help with any problem linked to swelling in shales, like in petroleum industry (stability of boreholes in shales) or tunnelling (interaction between shales and the support).

The mechanisms of water adsorption along smectites allows to better define the status of water in swelling claystones and shales containing, with a distinction between 
the adsorbed water (located within the platelets and made up of two layers strongly bonded along the smectite faces with suctions larger than $9 \mathrm{MPa}$ ) and the free water (located in the inter-platelets porosity, defining the pore pressure and submitted to water transfers). The MIP curve at initial state provides an idea of the proportions of the two types of water, with around $67 \%$ of free inter-platelets water and $33 \%$ of adsorbed intra-platelets water.

This distinction should have some consequences with respect to the poromechanical characteristics of the claystone that are used in the constitutive and numerical modelling developed to assess the response of the rock mass around the galleries, in the close field and at larger distance from the walls. According to the findings of this work, the active porosity to consider could be rather related to the interplatelets porosity, estimated to around $68 \%$ of the total porosity of the claystone. The poroelastic parameters used in calculations (including the Biot coefficient $b$ ) should also depend on the relative proportion between free and adsorbed water and further research in this direction is necessary. Comparable corrections should also be made with respect to water transfer properties, that should only involve the inter-platelet porosity.

The data obtained along the drying path show that drying up to suctions of various

hundreds of $\mathrm{MPa}$ are not too critical in terms of microstructure changes. It would then be interesting to better define the changes in suction with time along the gallery walls submitted to ventilation so as to assess possible related changes in microstructure. Along the wetting path, the data have some consequences in terms of laboratory testing, confirming that hydration with no stress applied can result in significant damage. Insitu, the more detailed description of wetting provided here could be of some interest when considering the microstructure changes and stress redistribution during the resaturation phase after the final closure of the disposal.

\section{Acknowledgements}

The authors are indebted to Andra, the French agency of radioactive waste disposal, who financially supported this research through the $\mathrm{PhD}$ thesis of the first author and who provided the specimens of Callovo-oxfordian claystone. 


\section{References}

[1] Ahmed S, Lovell CW, Diamonds S (1974). Pore sizes and strength of compacted clay. ASCE J. Geotech. Engng 100, No. 4:407-425

[2] ANDRA (2005). Synthesis argile: evaluation of the feasibility of a geological repository in argillaceous formation. http://www.andra.fr/international/ download/andra-international-en/document/editions/266va.pdf

[3] Bérend I, Cases JM, François M, Uriot JP, Michot LJ, Masion A, Thomas F (1995). Mechanism of adsorption and desorption of water vapour by homoionic montmorillonites: 2. The $\mathrm{Li}+, \mathrm{Na}+, \mathrm{K}+, \mathrm{Rb}+$ and $\mathrm{Cs}+$ exchanged forms. Clays and Clay Minerals 43:324-336

[4] Ben Rhaiem H, Pons CH, Tessier D (1985) Factors affecting the microstructure of smectites: role of cations and history of applied stresses, In: Schultz et al. (eds) Proc Int Clay Conf, Denver, The Clay Mineralogical Soc, pp 292-297

[5] Bornert M, Vales F, Gharbi H, Nguyen Minh D (2010). Multiscale full-field strain measurements for micromechanical investigations of the hydromechanical behaviour of clayey rocks Strain 46(1):33-46

[6] Boulin PF, Angulo-Jaramillo R, Daian JF, Talandier J, Berne P (2008). Pore gas connectivity analysis in Callovo-Oxfordian argillite. Applied Clay Science 42(1-2):276-283

[7] Caillère S, Hénin S and Rautureau M 1982. Minéralogie des argiles. I. Structure et propriétés physico-chimiques, $2^{\mathrm{ème}}$ édition, Masson, $184 \mathrm{p}$, Paris.

[8] Cases JM, Bérend I, François M, Uriot JP, Michot LJ, Thomas F (1997). Mechanism of adsorption and desorption of water vapour by homoionic montmorillonite: 3. The $\mathrm{Mg} 2+, \mathrm{Ca} 2+, \mathrm{Sr} 2+$ and $\mathrm{Ba} 2+$ exchanged forms. Clays and Clay Minerals 45:8-22

[9] Delage P, Pellerin FM (1984). Influence de la lyophilisation sur la structure d'une argile sensible du Quebec. Clay Minerals 19(2): 151-160

[10] Delage P, Lefebvre G (1984). Study of the structure of a sensitive Champlain clay and of its evolution during consolidation. Canadian Geotechnical Journal 21 (1):21-35

[11] Delage P, Howat M, Cui YJ (1998). The relationship between suction and swelling properties in a heavily compacted unsaturated clay. Engineering Geology 50(1-2):31-48 
[12] Delage P, Marcial D, Cui YJ, Ruiz X (2006). Ageing effects in a compacted bentonite: a microstructure approach. Géotechnique 56 (5):291-304

[13] Delage P, Menaceur H, Tang AM, Talandier J (2014). Suction effects in deep Callovo-Oxfordian claystone specimen. Géotechnique Letters 3(2), 84-88

[14] Diamond, S. (1970). Pore size distribution in clays. Clays Clay Miner 18:7-23

[15] Ferrage E, Lanson B, Sakharov BA, Drits VA (2005). Investigation of smectite hydration properties by modeling experimental X-ray diffraction patterns: Part I. Montmorillonite hydration properties. Am. Mineral. 90:1358-1374

[16] Ferrage E, Kirk CA, Cressey G and Cuadros J. (2007). Dehydration of Camontmorillonite at the crystal scale. Part I: Structure evolution. . Am. Mineral.92: 994 - 1006.

[17] Ferrari A, Favero V, Marschall P, Laloui L (2014). Experimental analysis of the water retention behaviour of shales. International Journal of Rock Mechanics and Mining Sciences 72:61-70

[18] Gaucher G, Robelin C, Matray JM, Négrel G, Gros Y, Heitz JF, Vinsot A, Rebours H, Cassagnabère, Bouchet A (2004). ANDRA underground research laboratory: interpretation of the mineralogical and geochemical data acquired in the Callovian-Oxfordian formation by investigative drilling. Physics and Chemistry of the Earth 29:55-77

[19] Gillott JE (1973). Methods of sample preparation for microstructural analysis of soil. Proc. 4th Int. Working Meeting on Soil Micromorphology, ed GK Rutherford, Kingston, 143-164

[20] Laird DA, Shang C, Thompson ML (1995). Hysteresis in crystalline swelling of smectites. Journal of Colloid and Interface Science 171:240-245

[21] Lebon P, Mouroux B (1999). Knowledge of the three French underground laboratory sites. Engineering Geology 52:251-256

[22] Méring J, Glaeser R (1954). Sur le rôle de la valence des cations échangeables dans la montmorillonite. Bulletin de la Société Francaise de Minéralogie et Cristallographie 77:519-530

[23] Mitchell JK, Soga K (2005). Fundamentals of soil behaviour. John Wiley NewYork

[24] Montes-Hernandez G, Duplay J, Martinez L, Escoffier S, Rousset D (2004). Structural modifications of Callovo-Oxfordian argillite under 
hydration/dehydration conditions. Applied Clay Science 25:187-94

[25] Mooney RW, Keenan AC, Wood LA (1952). Adsorption of water vapor by montmorillonite. II. Effect of exchangeable ions and lattice swelling as measured from X-ray diffraction. J. Am. Chem. Soc. 74:1371-1374

[26] Norrish K (1954). The swelling of montmorillonite. Discussions of the Faraday society, 18, 120-133

[27] Pham QT, Vales F, Malinsky L, Nguyen Minh D, Gharbi H (2007). Effects of desaturation-resaturation on mudstone. Physics and Chemistry of the Earth $32: 646-655$

[28] Saiyouri N, Tessier D, Hicher PY (2004). Experimental study of swelling in unsaturated compacted clays. Clay Minerals 39:469-479

[29] Sammartino S, Bouchet A, Prêt D, Parneix JC, Tevissen E (2003). Spatial distribution of porosity and minerals in clay rocks from the CallovoOxfordian formation (Meuse/Haute-Marne, Eastern France)-implications on ionics species diffusion and rock sorption capability. Applied Clay Science $23(1-4): 157-166$

[30] Sridharan A, Altschaeffl AG, Diamond S (1971). Pore size distribution studies. J. Soil Mech. Found. Div. ASCE 97 No. 5:771-787

[31] Tovey NK, Wong KY (1973). The preparation of soils and other geological materials for the scanning electron microscope. Proceedings of the International Symposium on Soil Structure, Gothenburg, Sweden, 176-183

[32] Valès F (2008). Modes de déformation et d'endommagement de roches argileuses profondes sous sollicitations hydro-mécaniques. $\mathrm{PhD}$ thesis, Ecole Polytechnique, Paris

[33] Wan M, Delage P, Tang AM, Talandier J (2013). Water retention properties of the Callovo-Oxfordian claystone. International Journal of Rock Mechanics and Mining Sciences 64: 96-104

[34] Wang LL, Bornert M, Héripré E, Yang DS, Chanchole S (2014). Irreversible deformation and damage in argillaceous rocks induced by wetting/drying. Journal of Applied Geophysics 107:108-118

[35] Wang LL, Bornert M, Héripré E, Chanchole S, Pouya A, Halphen B (2015). Microscale insight into the influence of humidity on the mechanical behavior of mudstones. Journal of Geophysical Research: Solid Earth 120: 3173-3186, doi:10.1002/2015JB011953 
[36] Wileveau Y, Cornet FH, Desroches J, Blumling P (2007) Complete in situ stress determination in an argillite sedimentary formation. Phys Chem Earth $\mathrm{A} / \mathrm{B} / \mathrm{C} ; 32(8-14): 866-78$

[37] Yven B, Sammartino S, Geroud Y, Homand F, Villieras F (2007). Mineralogy texture and porosity of Callovo-Oxfordian claystones of the Meuse/HauteMarne region (eastern Paris Basin), Mémoires de la Société géologique de France, ISSN 0249-7549, 178:73-90 


\section{List of Tables}

Table 1. Drying-wetting paths.

Table 2. Wetting-drying paths.

Table 3. Characteristics of the specimens at the end of each test.

Table 4. Porosity values obtained.

\section{List of Figures}

Figure 1. Changes in water content versus time from the initial state to various suctions.

Figure 2. Changes in water content versus time for the subsequent drying/wetting stages.

Figure 3. Water retention curve of the COx claystone obtained by suction control (vapour equilibrium) and by WP4 suction measurements (specimens A2, B2 and D2).

Figure 4. Water retention properties and volume changes obtained by suction control in terms of changes in degree of saturation and volume changes with respect to i) suction changes (a and c, respectively) and ii) water content ( $b$ and $d$, respectively).

Figure 5. Pore size distribution curves of specimen EST44584 at initial state: a) cumulative curve; b) density function.

Figure 6. Pore size distribution curves of specimen EST44584 at initial state, $150 \mathrm{MPa}, 331 \mathrm{MPa}$ and oven dry (enlargement below $0.1 \mu \mathrm{m}$ ): a) cumulative curves; b) density functions.

Figure 7. Pore size distribution curves of specimen EST44584 at initial state, $9 \mathrm{MPa}$ and $0 \mathrm{MPa}$ : a) cumulative curves; b) density functions.

Figure 8. Pore size distribution curves of specimen EST44584 at initial state, $9 \mathrm{MPa}$ (from initial state) and $9 \mathrm{MPa}$ (from dry state at $331 \mathrm{MPa}$ ): a) cumulative curves; b) density functions.

Figure 9. Pore size distribution curves of specimen EST44584 at initial state, brought from initial state to zero suction and brought to a suction of $331 \mathrm{MPa}$ and afterwards to zero suction: a) cumulative curves with curves adjusted at largest diameter; b) cumulative curves with curves adjusted at smallest diameter; c) density functions.

Figure 10. Pore size distribution curves of sample EST44584 at initial state, brought to a suction of 331 $\mathrm{MPa}$ directly from initial state and after previous wetting at zero suction.

Figure 11. Conceptual simplified model of COx clay microstructure (after Yven et al. 2007) and scheme of the brick model showing the correspondence between the average pore diameter and the brick (or platelet) thickness.

Figure 12. Hydration mechanisms in MX80 (after Sayiouri et al. 2004) investigated through X-Ray diffractometry.

Figure 13. a) Changes in mean MIP diameter of the COx specimen with respect to suction; b) changes in infra porosity with respect to suction 


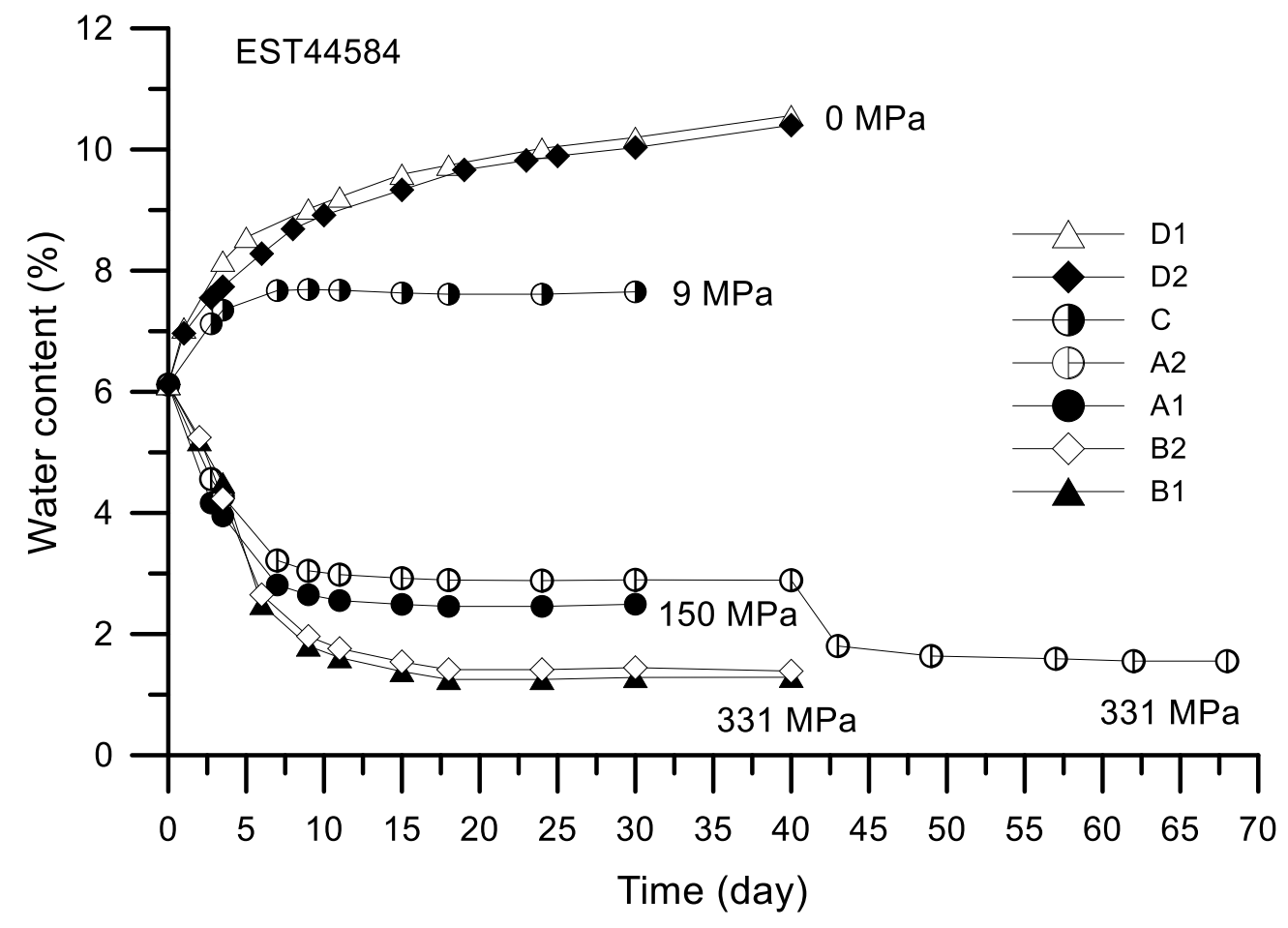




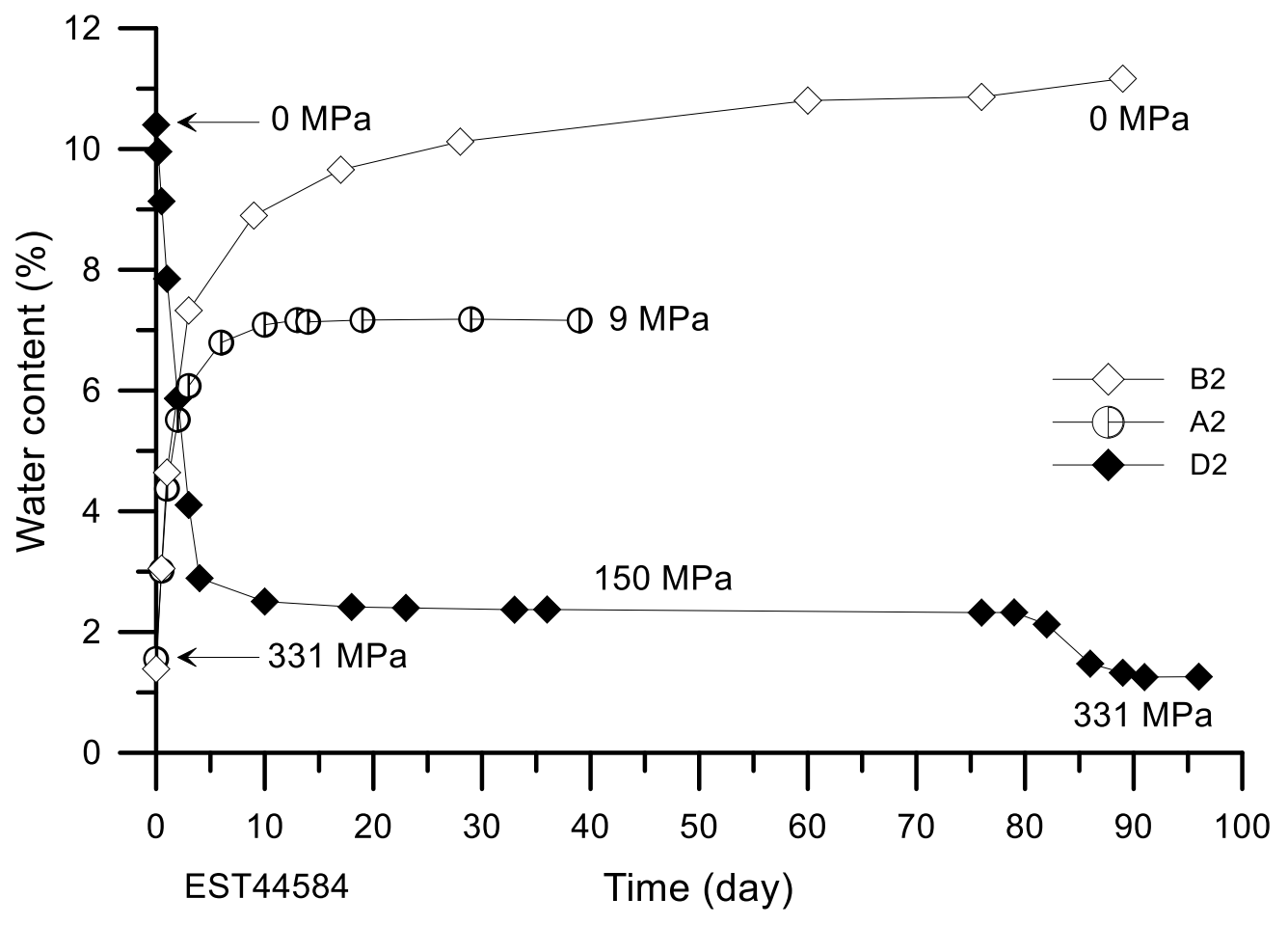




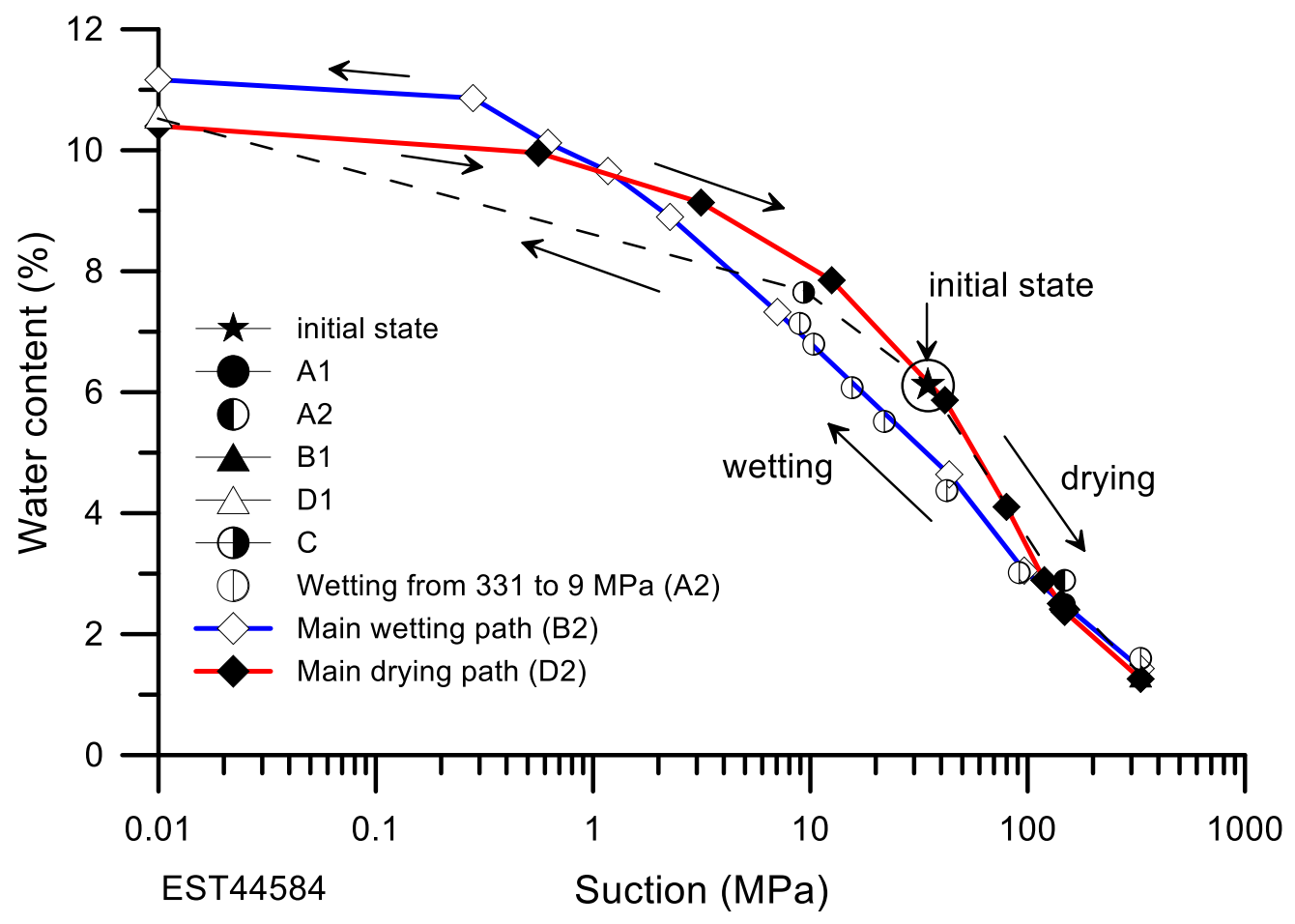



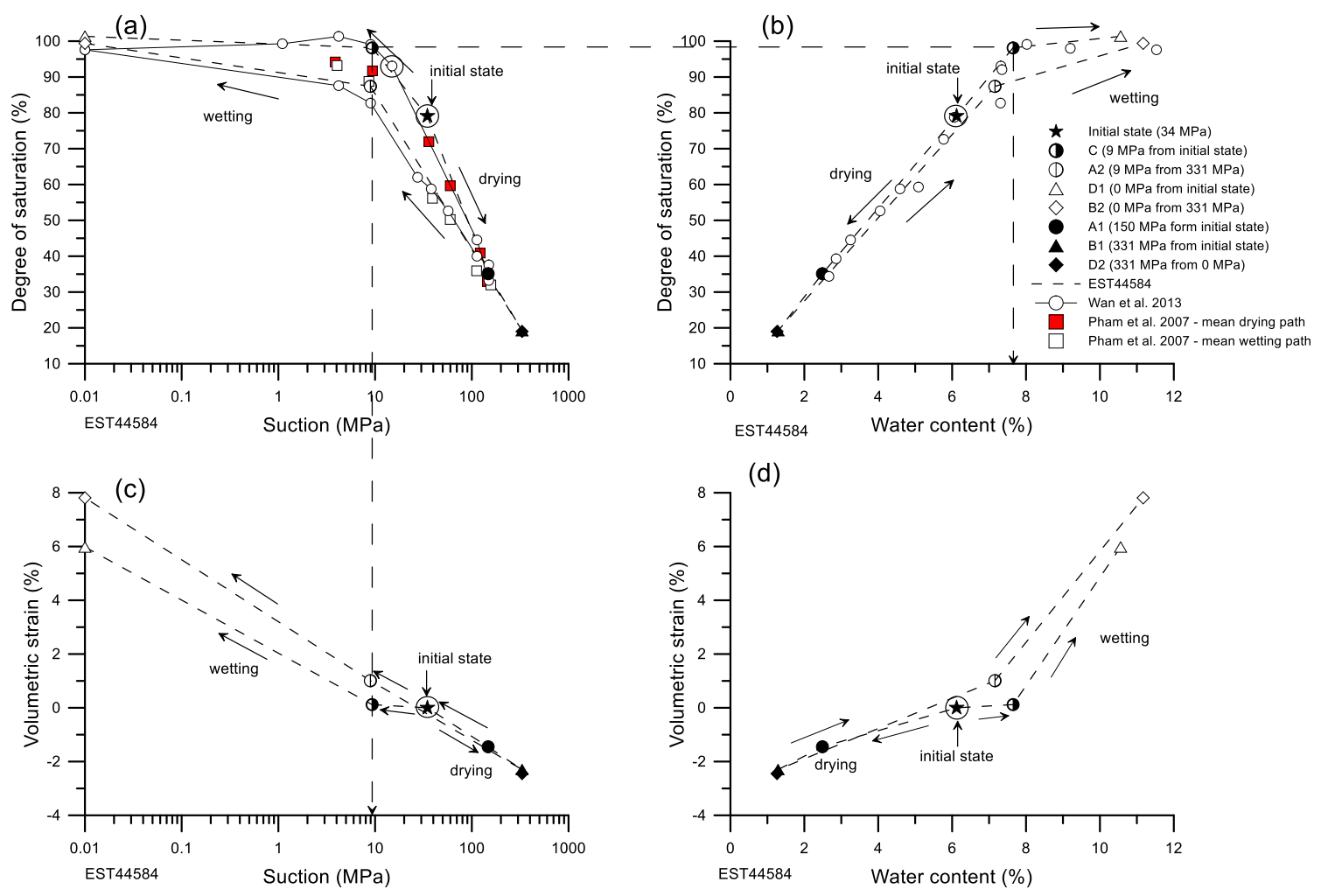

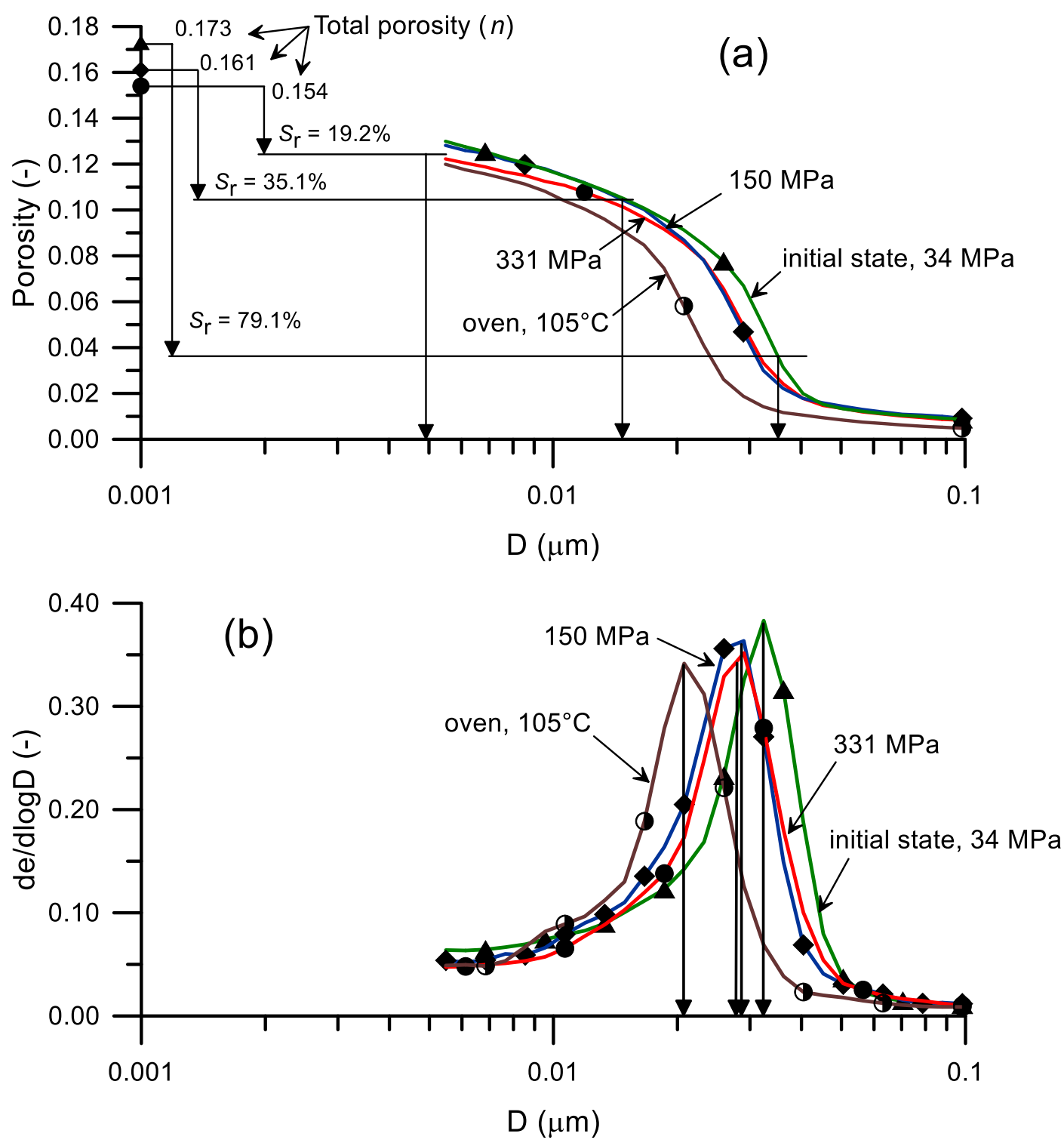

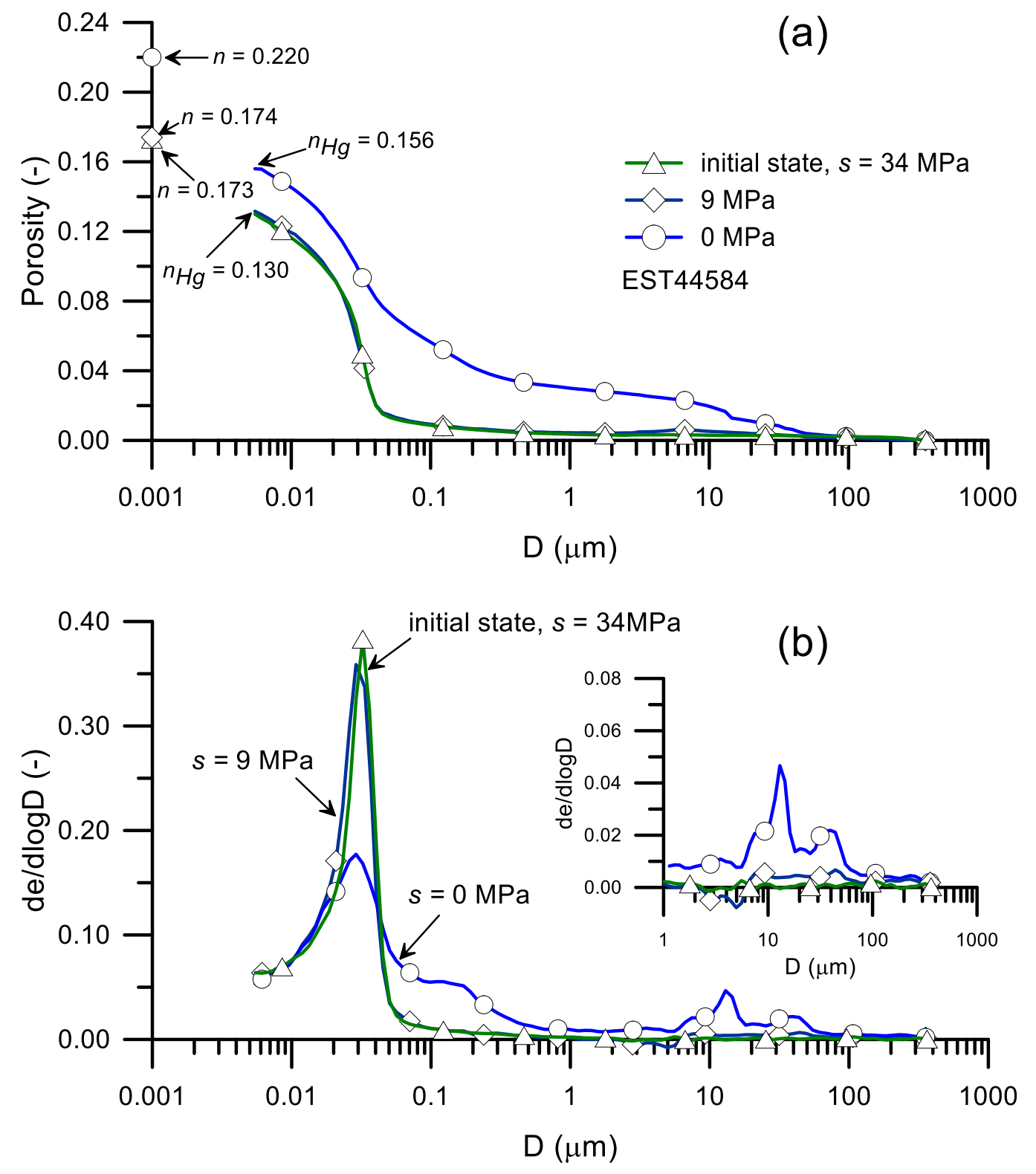

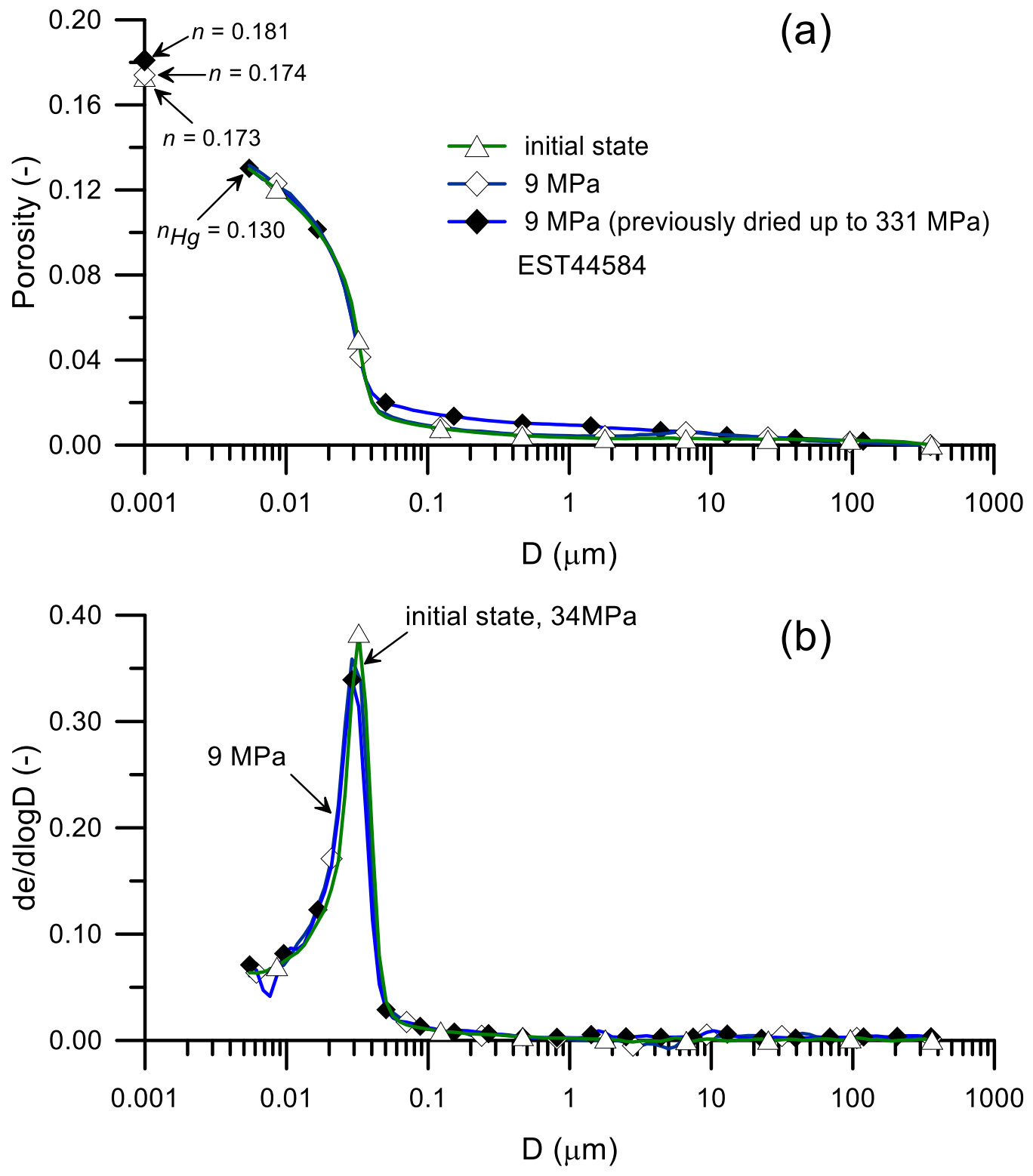

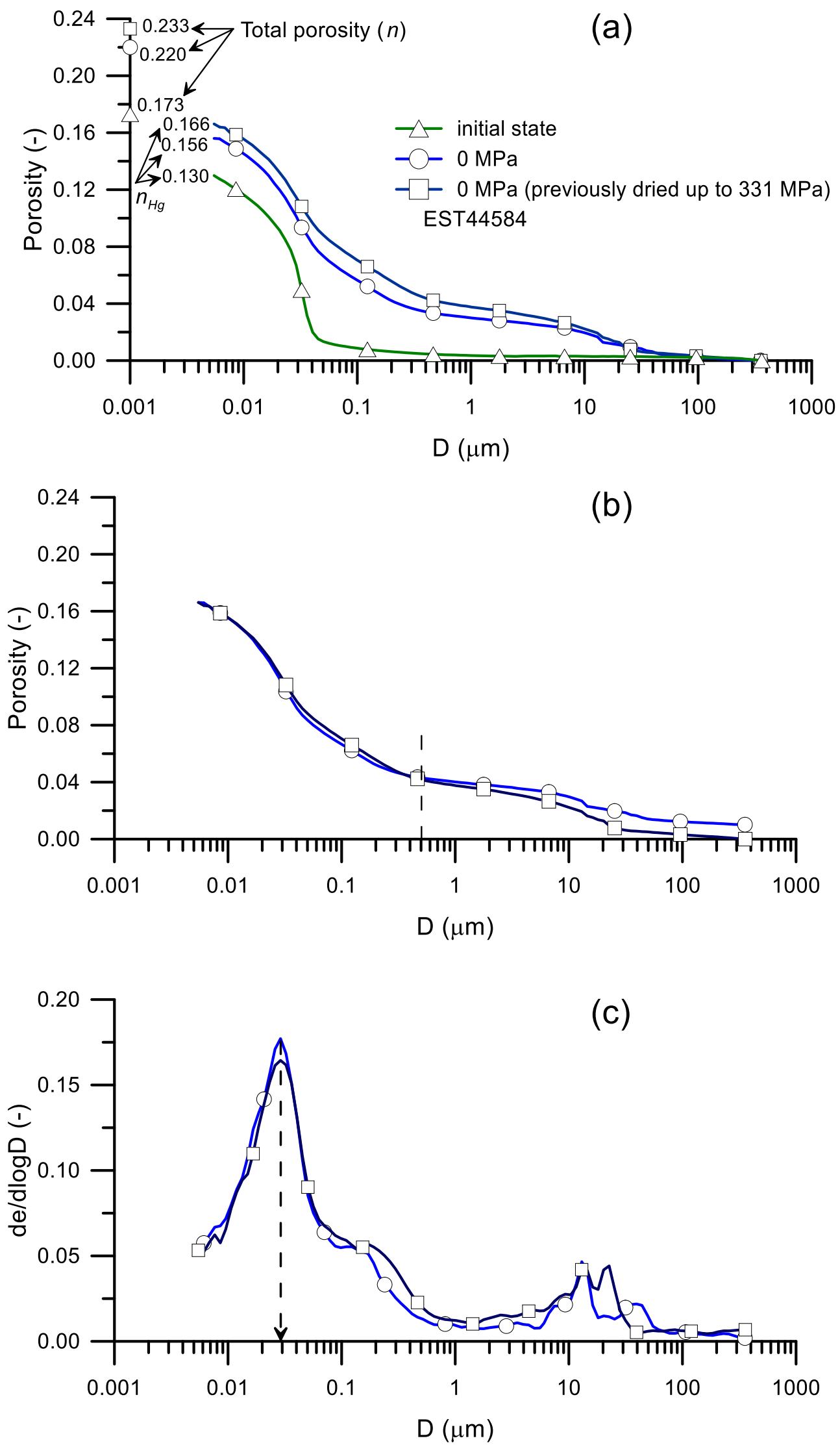

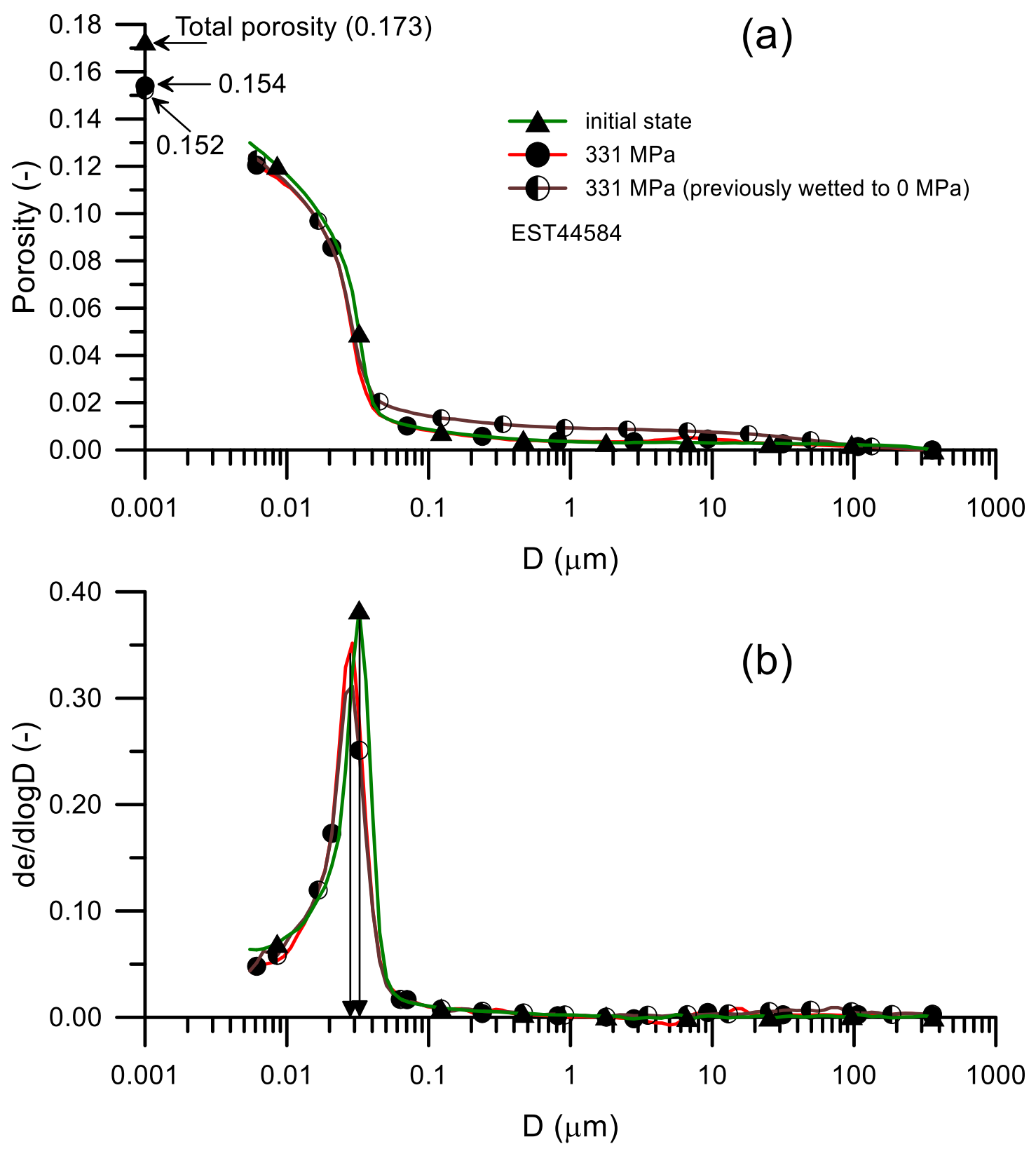


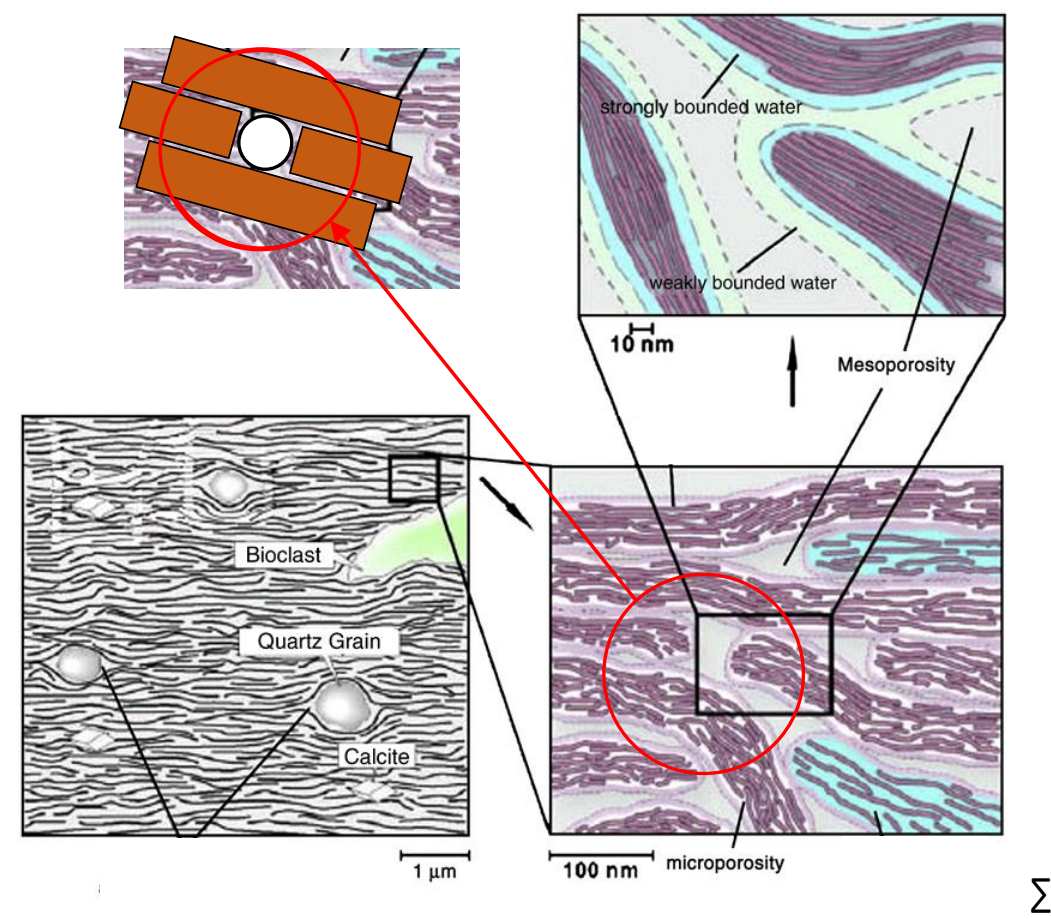




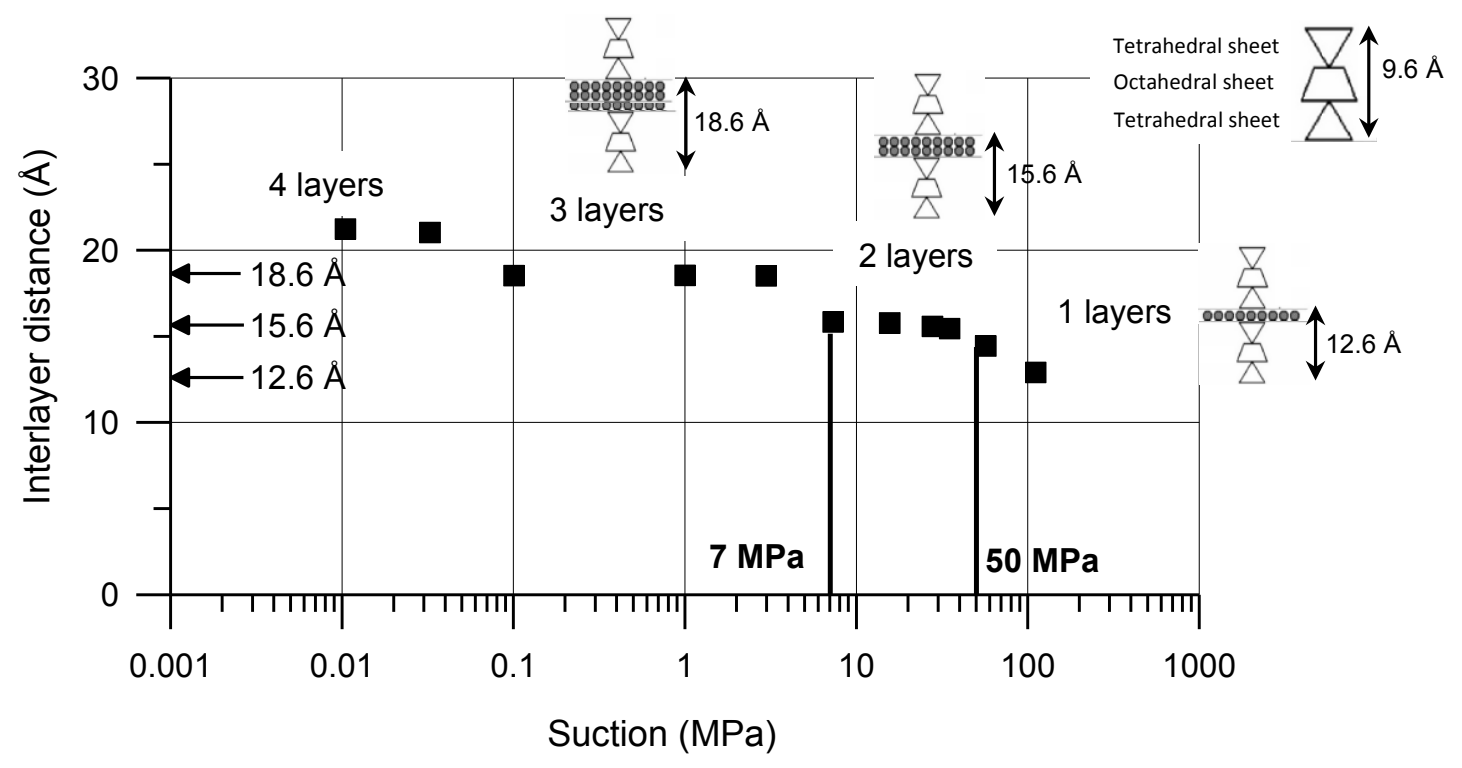



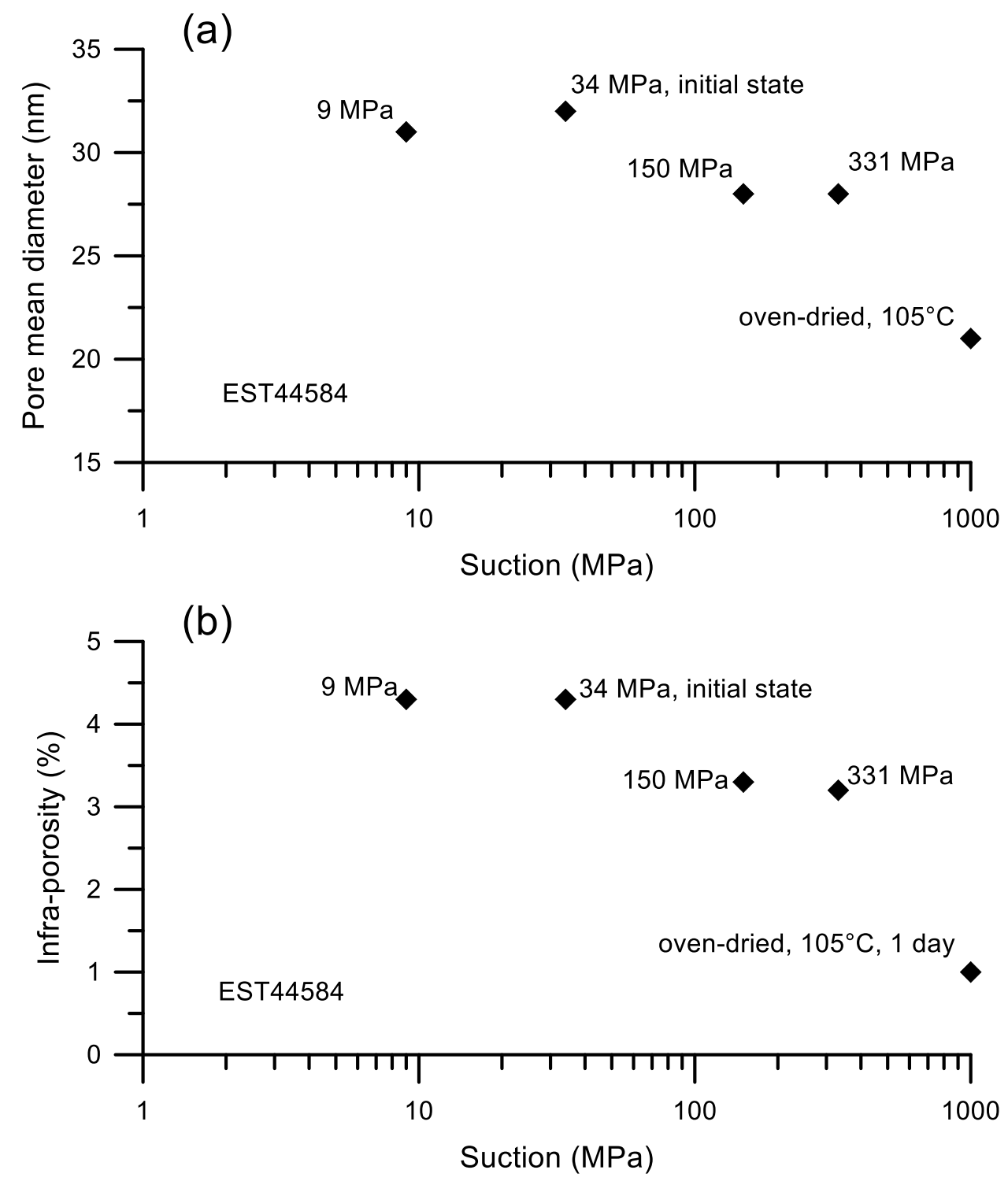

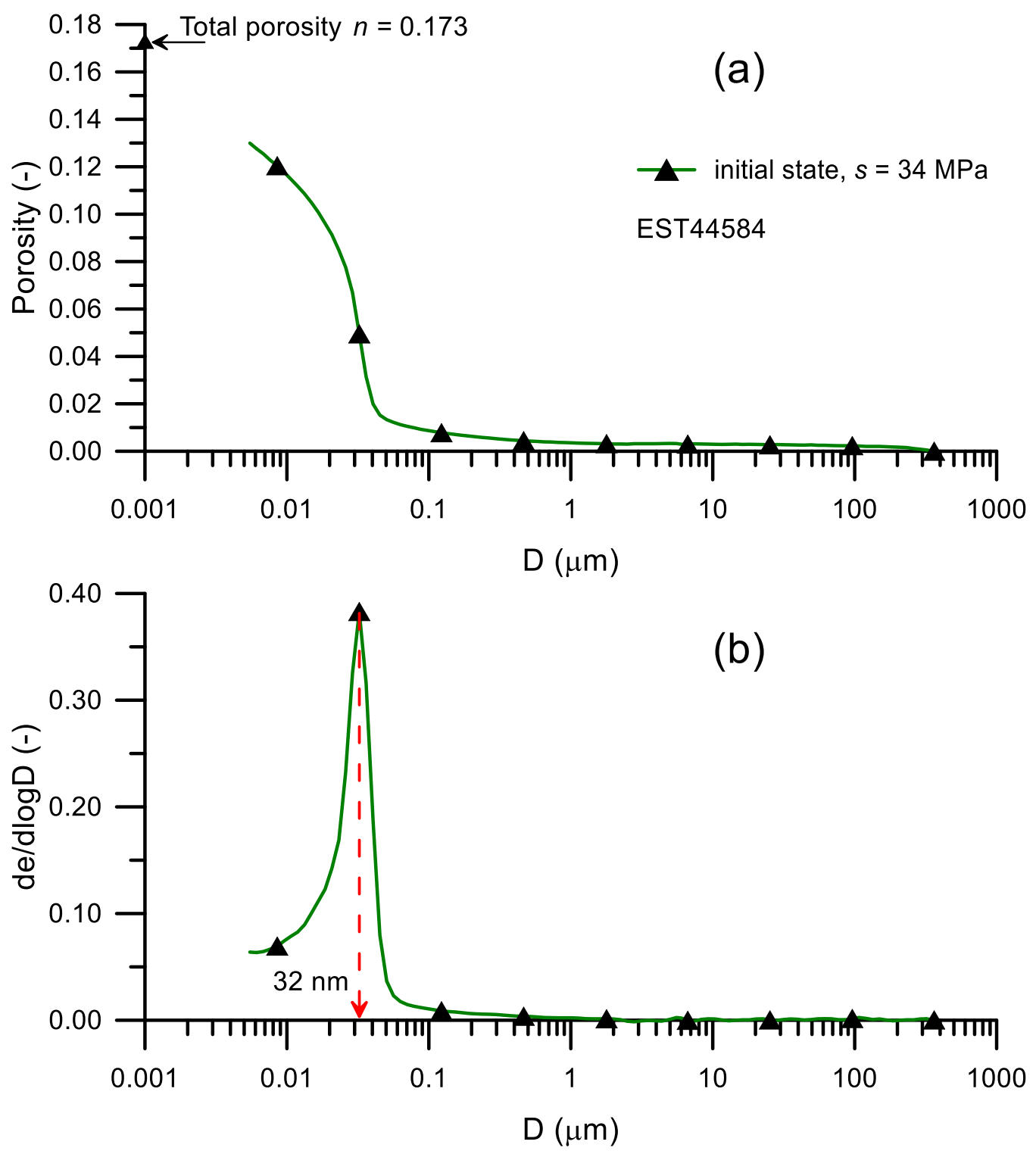
Table 1. Drying-wetting paths.

\begin{tabular}{|c|c|c|c|c|c|}
\hline Specimen & Initial state & $150 \mathrm{MPa}$ & $331 \mathrm{MPa}$ & $9 \mathrm{MPa}$ & $0 \mathrm{MPa}$ \\
\hline $\mathrm{A} 1$ & $\star$ & $\star$ & & & \\
\hline $\mathrm{A} 2$ & $\star$ & $\longrightarrow$ & $\longrightarrow$ & $\longrightarrow$ & \\
\hline $\mathrm{B} 1$ & $\star$ & & $\rightarrow$ & \\
\hline $\mathrm{B} 2$ & $\star$ & & $\longrightarrow$ & & \\
\hline
\end{tabular}


Table 2. Wetting-drying paths.

\begin{tabular}{|c|c|c|c|c|c|}
\hline Specimen & Initial state & $9 \mathrm{MPa}$ & $0 \mathrm{MPa}$ & $150 \mathrm{MPa}$ & $331 \mathrm{MPa}$ \\
\hline $\mathrm{C}$ & $\star$ & $\longrightarrow$ & & & \\
\hline $\mathrm{D} 1$ & $\star$ & & $\longrightarrow$ & & \\
\hline $\mathrm{D} 2$ & $\star$ & & $\longrightarrow$ & $\longrightarrow$ & $\longrightarrow$ \\
\hline
\end{tabular}


Table 3. Characteristics of the specimens at the end of each test.

\begin{tabular}{ccccccc}
\hline Specimen & Suction $(\mathrm{MPa})$ & $\Delta \mathrm{V} / \mathrm{V}(\%)$ & $w(\%)$ & $e$ & $n(\%)$ & $S_{r}(\%)$ \\
\hline Initial state & 34 & - & 6.12 & 0.209 & 17.3 & 79.1 \\
D1 & 0 & 5.98 & 10.56 & 0.281 & 22.0 & 101.4 \\
B2 & 0 & 7.81 & 11.16 & 0.303 & 23.3 & 99.4 \\
C & 9 & 0.12 & 7.65 & 0.21 & 17.4 & 98.1 \\
A2 & 9 & 1.01 & 7.16 & 0.221 & 18.1 & 87.4 \\
A1 & 150 & -1.45 & 2.49 & 0.191 & 16.1 & 35.1 \\
B1 & 331 & -2.25 & 1.29 & 0.182 & 15.4 & 19.2 \\
D2 & 331 & -2.45 & 1.26 & 0.179 & 15.2 & 19.0 \\
\hline
\end{tabular}


Table 4. Porosity values obtained.

\begin{tabular}{lccccc}
\hline Specimen & $\begin{array}{c}\text { Suction } \\
(\mathrm{MPa})\end{array}$ & $\begin{array}{c}\text { Intruded porosity } \\
n_{H g}\end{array}$ & $\begin{array}{c}\text { Total porosity } \\
\text { total volume } \\
\text { measurement }\end{array}$ & $\begin{array}{c}\text { Total porosity } \\
\text { hydrostatic } \\
\text { weighing }\end{array}$ & $\begin{array}{c}\text { Infra porosity } \\
n-n_{H g}\end{array}$ \\
\hline Initial state & 34 & 13.0 & 17.3 & $n$ & \\
D1 & 0 & 15.6 & 22.0 & 22.7 & 4.3 \\
B2 & 0 & 16.6 & 23.3 & 23.2 & 6.4 \\
C & 9 & 13.1 & 17.4 & 17.5 & 6.7 \\
A2 & 9 & 13.0 & 18.1 & 17.9 & 4.3 \\
A1 & 150 & 12.8 & 16.1 & 16.2 & 5.1 \\
B1 & 331 & 12.2 & 15.4 & 15.6 & 3.3 \\
D2 & 331 & 12.4 & 15.2 & 15.2 & 3.2 \\
\hline
\end{tabular}

